The

Carl Beck

Papers

in Russian \&

East European Studies

Susan Smith-Peter

Number 1908

\title{
The Russian Provincial Newspaper and Its Public, 1788-1864
}

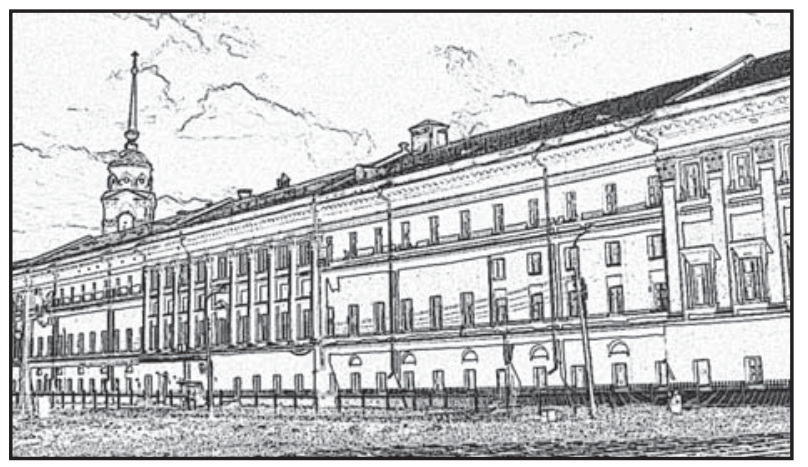


The

Carl Beck

Papers

in Russian \&

East European Studies

Number 1908

Susan Smith-Peter

The Russian Provincial Newspaper and Its

Public, 1788-1864 
Susan Smith-Peter is currently Assistant Professor of History at the City University of New York, College of Staten Island. She received her Ph.D. from the University of Illinois at Urbana-Champaign in 2001. She has published in a wide variety of topics dealing with the circulation of knowledge in pre-reform Russia in such journals as The Russian Review, Russian History/Histoire Russe, History of Science, Kritika and Library History. She is presently at work on a monograph, Regions and Regionalism in the Russian Empire, 1830-1917, that explores the unexpectedly advanced nature of regional identity and political regionalism in Siberia and elsewhere.

No. 1908, October 2008

(C) 2008 by The Center for Russian and East European Studies, a program of the University Center for International Studies, University of Pittsburgh

ISSN 0889-275X

Image from cover: Vladimir's Prisutstvennykh mest, the office building where the vedomosti were produced. Photograph taken by author.

The Carl Beck Papers

Editors: William Chase, Bob Donnorummo, Ronald H. Linden

Managing Editor: Eileen O’Malley

Editorial Assistant: Vera Dorosh Sebulsky

Submissions to The Carl Beck Papers are welcome. Manuscripts must be in English, double-spaced throughout, and between 40 and 90 pages in length. Acceptance is based on anonymous review. Mail submissions to: Editor, The Carl Beck Papers, Center for Russian and East European Studies, 4400 Wesley W. Posvar Hall, University of Pittsburgh, Pittsburgh, PA 15260. 


\begin{abstract}
This work examines the rise of the provincial newspaper from its origins in Tambov under the poet and governor Gavrila Derzhavin to its widespread dissemination under Nicholas I. The newspapers included an official section, which was filled with official announcements and orders, as well as an unofficial section dealing with the province. The state's aim was to increase the flow of official information to and from the provinces. They did not expect to stimulate local society and encourage the growth of regional identity, but these were among the unintended effects of the newspapers. In particular, the unofficial section became a forum for provincial readers and writers to study their corner of the empire in all its historical, ethnographic, statistical, and archaeological facets. This helped to lay the foundation for an active civil society during the reign of Nicholas I.
\end{abstract}

[Minister of Internal Affairs D. N.] Bludov ordered that each provincial Government should publish its own Gazette, and that each Gazette should include, as well as the official news, a department for history, literature and the like. No sooner said than done. In fifty [sic] provincial governments they were soon tearing their hair over this unofficial part. Priests from the theological seminaries, doctors of medicine, schoolmasters, anyone who was suspected of being able to spell correctly-all these were pressed into the service. These recruits reflected, read up the leading newspapers and magazines, felt nervous, took the plunge, and finally produced their little articles. To see oneself in print is one of the strongest artificial passions of an age corrupted by books. But it requires courage, nevertheless, except in special circumstances, to venture on a public exhibition of one's productions. People who would not have dreamed of publishing their articles in the Moscow Gazette or the Petersburg newspapers, now began to print their writings in the privacy of their own houses. Thus the dangerous habit of possessing an organ of one's own took root, and men became accustomed to publicity. And indeed it is not a bad thing to have a weapon always ready for use.

—Alexander Herzen, My Past and Thoughts 
In 1837, the Ministry of Internal Affairs ordered that newspapers (gubernskie vedomosti) with both official and unofficial sections be established in forty-two provinces. These newspapers served as the focal point for the development of a provincial public interested in the past and present of their region. The newspaper encouraged the spread of social networks, thus expanding and strengthening the nascent public. Such social networks involved personal relationships and connections to voluntary associations and government institutions. Ian McNeely's work on the German intelligence gazettes, which were equivalent to the vedomosti, argues that the newspaper was at the center of the development of civil society in late eighteenth- and early nineteenth-century Württemberg. The intelligence gazettes served to map and expand official and unofficial networks (a process he analyzes using the concepts of formality, collegiality, and sociography) within the context of encyclopedism, or the systematic cataloging of as many objects as possible. These concepts, he writes, "possess the virtue of not presuming the very distinction-that between state and civil society - they purport to dissect. This is because they locate power indiscriminately among the various players in the narrative: scribes, other state officials, and everyday citizens."

I argue that a parallel development occurred in Russia where members of various estates came together to study all aspects of the region and in so doing created and expanded social networks in the bureaucracy and society, thus laying the foundation for a Russian civil society. I place this work in the expanding literature on the history of civil society in Russia. Douglas Smith noted that although Russian eighteenth-century civil society was dominated by the nobility, "it shared this space with individuals from various backgrounds and social stations including state officials of different ranks, professors, men of letters, clergymen, noblewomen, merchants, and other representatives of the free professions.... The social composition of the Russian public was similar to that in other European countries where the core of the public was formed not from a bourgeoisie in the traditional economic sense, but from the growing ranks of educated state officials and administrators, extending outward to include scholars, military officers, writers, and other social groups that constituted the educated classes."2 In studying Russia’s civil society, Joseph Bradley proposed "a change of emphasis from what did not happen to what did." 3 In other words, we can look beyond the existence of a Russian bourgeoisie (or lack thereof) and, in so doing, gain a sharper understanding of the social groups at work in the Russian Empire. Much of the work on Russian civil society has focused on the eighteenth century or the postreform era, and often on the zemstvo, because local self-government allowed society a measure of political power. ${ }^{4}$ Much less has been written on the first half of 
the nineteenth century. During this time, however, the foundations of public activity were laid by individuals from various estate backgrounds interested in studying and sometimes critiquing local conditions. The roots of the zemstvo were intertwined with the vedomosti and other institutions established in the 1830s to catalog the regions. These institutions provided the necessary underpinning for the phenomenal growth of public activity during the Great Reforms and after. It has become increasingly clear that a civil society cannot be airlifted into a country, but rather must grow over time.

This work fits into a larger historiography that emphasizes the agency of the provinces. ${ }^{5}$ The provinces were active shapers of their own culture rather than passive repositories of central activity. For example, the chronicle tradition of early modern Russia remained a living genre in the provinces through the 1830s. ${ }^{6}$ Daniel Waugh notes that provincial chronicles of the early eighteenth century at times tied their histories to the center and at other times emphasized their independence or isolation. ${ }^{7}$ By the late eighteenth century, the provinces had absorbed new trends from the capitals, such as sentimentalism and Freemasonry, that were reflected in the publishing activity of the provincial presses. ${ }^{8}$ In several provinces, the vedomosti developed as a continuation of an earlier manuscript and print culture rather than as a top-down imposition. However, the vedomosti were not permitted to write about national issues, which had the effect of boosting the isolationist tradition of chronicle writing and focusing attention on local specifics.

The development of the vedomosti has attracted attention from Russian scholars. Two classic accounts of the prerevolutionary period by N. M. Lisovskii and S. A. Vengerov criticized the newspapers for their neutrality in political debates, a position often repeated in general Soviet works. ${ }^{9}$ Many studies of newspapers were written within the encyclopedic tradition of local studies (kraevedenie).${ }^{10}$ Other studies cast the newspapers within the history of the revolutionary movement, focusing on the editorial work of political exiles such as Alexander Herzen in Vladimir. ${ }^{11}$ However, these authors needed to justify their study of the newspapers by emphasizing their progressive nature, and not all the newspapers fit into that mold. Post-Soviet works have been able to ask different questions, such as the role of the vedomosti in popularizing science ${ }^{12}$ However, few have used provincial archival materials to explore the inner workings of such newspapers, partly because the archives of many papers were not preserved. ${ }^{13}$

Given the tight censorship of the era of Nicholas I (1825-1855), archival sources, always important for historical research, are of great significance; many conflicts are revealed in the archives rather than in what the censors allowed to be published. For this essay I have used both central and provincial archives, along with a wide variety 
of primary and secondary sources, to explore the tensions elided in print. I hope to draw scholars' attention to the vedomosti, as they provide an unparalleled source for the economic, legal, cultural, and social history of the provinces (for example, a complete price series for key products from 1838 to 1917 in forty-two provinces). ${ }^{14}$ For intellectual and cultural history, they provide a rich alternative source for the study of such figures as Herzen, M. E. Saltykov-Shchedrin, and the Petrashevtsy.

Provincial newspapers had both official and unofficial sections, and the latter developed into a forum for the study of the region. By the 1850s, it included articles on the history, archaeology, ethnography, geography, and statistics of the province. Although there was governmental resistance to establishing an unofficial section, it was created in reaction to the vast size of Russia and the military-economic imperative to chart the country as fully as possible. The lack of university-educated civil servants complicated the task. The unofficial section, which called upon locals to write about their region, built upon earlier efforts. Peter the Great was the first to seek "partners for bringing his plans to fruition by asking for the support of the educated elite." 15 In line with the Petrine tradition of controlled public engagement, the Academy of Sciences by the 1750s had identified useful local correspondents during the course of its scientific expeditions. After a visit by one such expedition to Arkhangel'sk in the 1750s, two local merchants founded the first local history association, the Society for Historical Research, in Arkhangel'sk in 1759. Catherine the Great established the general survey to produce detailed maps and topographical descriptions, which continued through $1861 .^{16}$

During the 1830s, Nicholas I supported administrative reform partly as a response to the weaknesses of provincial administration made visible during the cholera years of the early 1830s. ${ }^{17}$ As part of this administrative reform, a law was promulgated in 1834 establishing statistical committees in the European provinces in order to collect historical, geographical, topographical, ethnographic, and archeological information. These topics also formed the basis of the unofficial section of the newspapers. The statistical committees were to include as many local worthies as possible in order to broaden the source base, which until then had been limited to the local police. ${ }^{18}$ Again, the hope was that local volunteers would be able to supplement the materials gathered by central bureaucrats. Nicholas I did not make a radical break with the Petrine tradition of carefully contained public engagement. The new institutions of the 1830s were not meant to create a provincial public capable of independent action; however, many important consequences in history are unintended.

Statistics became the language of the local. In the 1830s, statistics was primarily a qualitative practice - with a liberal slant. Statistical descriptions drew from other 
genres, such as travel writing, and from earlier topographical descriptions. While it is often said that literature was the only way for the educated public to comment on serious social issues, statistics formed an alternative outlet for public debate. K. I. Arsen'ev, the era's leading statistician, emphasized the well-being of the population as the fundamental test of the government's efficacy. ${ }^{19}$ In the decades before 1861, statistical writings were often used to criticize serfdom and other problems. In Russia, as in Western Europe, “the appropriation by the 'public' of this language of power is perhaps the most distinctive trait of statistics in the nineteenth century." 20 For example, an 1847 statistical description of area mines in the Kazan Provincial Newspaper criticized the old equipment in the mines, the shortage of engineers, the lackadaisical attitude of owners, the poor treatment of the workers, and the use of child labor. ${ }^{21}$ Because statistics had the aura of science and objectivity, criticisms that censors never would have allowed in more literary forms were published in statistical essays.

This work uses the Vladimir Provincial Newspaper (Vladimirskie gubernskie vedomosti) as a case study because it was a first-rank newspaper in terms of the quantity and quality of its articles ${ }^{22}$ and because it had a highly developed social network. As different newspapers in different regions were of varying quality, it is impossible to study one as representative of all others, but by studying one of the first tier and its links to others, we can get a sense of what the most developed newspapers were doing. It makes more sense to study the best, as the second- and third-tier papers had weaker social networks and often consisted mainly of reprints from other sources. Vladimir is an especially interesting choice because it included the advanced textile industry based in Ivanovo and so shows earlier than elsewhere the kinds of tensions industrialization provoked. In addition, the local merchantry was composed of modernizing Old Believer textile magnates who wrote for the newspaper, thus giving them a voice. Finally, the Vladimir paper helps to balance out the Soviet emphasis on more liberal and radical papers. Although these papers existed, many others, like Vladimir's, focused on history, archaeology, and statistics rather than on providing veiled political commentary.

\section{The Origins of the Provincial Newspaper}

The origins of the provincial newspaper lie in the provinces, not the center. Those involved echo the composition of eighteenth-century civil society as described by Douglas Smith: bureaucrats, merchants, professionals, and other members of the educated classes. Although the original idea of the newspapers was to disseminate 
governmental information to a broad public, conflicts soon arose about how much should be revealed — a tension found throughout the papers' history. The first provincial newspaper was published in 1788 in Tambov. The poet Gavrila Derzhavin, who was the governor of Tambov from 1785 to 1788, was the "inspiration, editor, and overseer" of the Tambov News (Tambovskie izvestiia), published in forty-nine folio issues in $1788 .{ }^{23}$ He explained his motivations in a letter to a fellow member of the Novikov Typographical Company, Prince Nikolai Trubetskoi, in August 1786. "Due to the size of this province and to the multitude of government affairs, there is an extremely high number of papers, which would be more quickly processed by a printing press . . . [than by] maintaining a multitude of unnecessary clerks; I have decided to establish here a press solely for government work." ${ }^{24}$ However, after receiving a reply from $\mathrm{N}$. I. Novikov outlining all the purchases needed to establish a press, Derzhavin decided to establish a free (vol'naia) press run by a German, Jurgen Schneider, perhaps to allow greater latitude for types of publications and to save money. ${ }^{25}$ According to Derzhavin, the Tambov newspaper would include "news of important people and parties traveling through the provinces and of prices of goods, and especially grain in the bazaars;" the latter item was meant to keep provisions commissioners from raising grain prices far above the published figures. ${ }^{26}$ According to Derzhavin, each week his office kept a list of items to be proclaimed, and on Friday, the provincial board was ordered to publish them. Over the weekend, the items were printed on a folio sheet in the form of a table that could be posted on walls. On Monday, the sheets were sent out to the provincial boards, lower courts, and churches to be posted. In this way, the authorities and the public would learn about "contracts and tax farmers, about runaway recruits ... and the prices of grain, which will restrain the arbitrariness and abuses of provision commissioners." 27

After the publication of the first issue in January 1788, Derzhavin sent a copy to his superior, Governor-General I. V. Gudovich, with whom he had earlier clashed. Gudovich objected a report on a band of thieves who had committed many thefts in two Tambov districts and their capture, for, as he said, "first, the notification of past thefts brings nothing pleasant to the public, and second, there is still no reliable news on their capture." Gudovich then requested Derzhavin to send copies to his attention before publishing, thus establishing the first censorship regime for provincial newspapers. ${ }^{28}$ Items in the newspaper included reports from district town dumas, accounts of sermons and other town events, and notices on promotions and transfers of civil and ecclesiastical personnel. The print historian V. Semennikov noted that the paper "was a direct forerunner of the present provincial newspaper. We see that the paper included one of the most important sections of provincial newspapers- the local chronicle.”29 
Given the newspapers' emphasis on the publication of grain prices as a check on provisions commissioners, it is interesting to note that Derzhavin left Tambov in the wake of a conflict with one such commissioner involving treasury money, which led to many charges and countercharges. ${ }^{30}$ In addition, the newspaper had printed correspondence singling out a district-level provincial board in a way that enraged Gudovich, who insisted on being the sole censor of the paper; Derzhavin called this "completely unacceptable" and soon after resigned his post. ${ }^{31}$ The newspaper did not survive Derzhavin's departure, but it established a model for the more solidly institutionalized provincial newspapers of the 1830s, which also covered the movement of important people, the price of goods, and town events.

The direct forerunner of the vedomosti was the Kazan News (Kazanskie izvestiia). Kazan was very important to the development of a provincial press due to the establishment in 1804 of Kazan University and the Kazan Educational District, which stretched more than twenty-eight hundred miles from Kazan to Kamchatka. Kazan, its intellectuals argued, was the capital of Eastern Russia and had as much to do with the East as the West. Originally, the Kazan News was privately owned by an adjunct professor, I. I. Zapol'skii, who, in 1809, asked the university and the Ministry of Education for permission to establish a newspaper to serve "the mutual needs of the residents," among whom, he wrote, there was "an attitude . . . exactly like that found in the capitals." ${ }^{32}$ As a result, he argued, Kazan residents deserved a newspaper equivalent to the Moscow Newspaper (Moskovskie vedomosti) or the St. Petersburg Newspaper (Sankt-Peterburgskie vedomosti). The paper was to focus on economic news aimed largely at a merchant audience. When the Ministry of Education, the university's superior, refused, demanding instead a focus on educational news, Zapol'skii appealed to the Ministry of Internal Affairs (MVD). He gained the protection of the Governor of Kazan, B. A. Mansurov, who asked the MVD for permission to print the paper on the press of the provincial government board. This created a struggle between ministries that was resolved in the MVD's favor by the Committee of Ministers in 1809. ${ }^{33}$ The new MVD program for the Kazan News was even more economic in nature; it stated that lack of information was stifling trade and, in particular, lack of information on prices hurt merchants and traders and profited sometimes unscrupulous middlemen. ${ }^{34}$ Minister of Education A. K. Razumovskii was embittered by this loss. On July 22, 1811, he received Alexander I's permission to order the transfer of the newspaper to the university, thus ending the MVD's control, but not before they had experienced the usefulness of such a paper.

In 1828, Minister of Finance E. F. Kankrin proposed the establishment of provincial newspapers on an empire-wide basis to the Committee of Ministers. The 
newspapers, he argued, should "be like the Kazan News" in publishing local material and selling classified advertisements. ${ }^{35}$ His proposal argued that provincial newspapers would stimulate trade and industry. ${ }^{36}$ This was in keeping with his lifelong focus on increasing the "capital of knowledge" in order to develop the economy by spreading information and skills. ${ }^{37}$ Kankrin's other projects included the publication of the Journal of Manufacturing and Trade, along with specialized journals for mining, forestry, and agriculture. ${ }^{38} \mathrm{He}$ was aware of the need to distribute useful information more broadly than could be done by relying solely on central publications.

In his 1828 proposal, Kankrin wrote that, "the Baltic provinces greatly benefit from the publication of various provincial and town newspapers, but, as of yet, it is impossible to wait until private individuals establish them in other provinces." ${ }^{39}$ This is only partly fair to the provinces. From the 1770s, certain towns or regions had fostered a strong print culture, arising from a continuing manuscript tradition that drew from the town chronicle and newer manuscript genres such as literary albums and Masonic writings. Specifically, the towns of Iaroslavl, Tambov, Tobolsk, Kostroma, and Riga, and the villages of Kazinka, Klintsy, and Ruzaevka established private presses during the $1780 \mathrm{~s} .{ }^{40}$ The government closure of private presses in 1796 led to a serious decline in provincial print culture. With the new university statute in 1804, however, publishing began to flourish in the university towns and districts of Kazan and Kharkov. At times the government hindered the development of printing, as in the case of Irkutsk, where the government refused requests to establish a provincial newspaper in the 1820s; a newspaper was founded there only in $1857 .{ }^{41}$ At the same time, however, we should not imagine that provincial print culture languished only due to government repression. Many provinces lacked a tradition of manuscript or print culture. If the goal was to establish newspapers throughout the provinces, only a direct order of the government would have brought it to fruition.

\section{The Unofficial Section}

Although it would not seem that a socially active newspaper could result from a government order, the creation of the unofficial section made it possible by bringing together a cross section of the local educated public. Early in 1829, Nicholas I agreed to create an interministerial committee to develop the legal framework for the provincial newspapers, which originally did not include an unofficial section. The next year, he approved the law on the provincial papers, which forbade the publication of political themes and permitted the publication of government orders, personal announcements, and other news. In 1830, several provinces were ordered to start newspapers as experiments: Astrakhan, Kazan, Kiev, Nizhnii Novgorod, 
Ukraine, and Iaroslavl. ${ }^{42}$ All were important economic and cultural centers. Kankrin wrote that they needed newspapers the most "due to the strength of their economic development." 43 The Ministry of Internal Affairs had jurisdiction over the papers, which would be administered by the provincial governors. ${ }^{44}$

Rather than legislating an official and unofficial section, the original 1830 statute listed four sections. The first section was largely devoted to laws and announcements from the central government, while the second carried information from the provincial treasury. The third section featured local official and unofficial news and information, thus containing the kernel of what would later become the unofficial section: "Various statistical and historical news, such as: a) news of the building of towns, important buildings, etc.; b) on the discovery of antiquities and objects worthy of notice." 45 The fourth section consisted of private announcements regarding runaway serfs, lost items, and the sale of property. ${ }^{46}$

The first governmental provincial newspaper was published in Iaroslavl in 1831. The paper created the division between official and unofficial sections and served as a model for later provincial newspapers in its layout and content. None of the other provinces mentioned in the 1830 statute published a paper before 1838. Iaroslavl had the strongest print culture of any provincial town in the Russian heartland. It was the site of the first provincial journal, The Solitary Bumpkin (Uedinennyi poshekhonets), published in 1786, and it had the first provincial theater, the first private provincial press, and the first provincial agricultural society in central Russia. ${ }^{47}$ The first issue of the Iaroslavl Provincial Newspaper (Iaroslavskie gubernskie vedomosti) was published on March 6, 1831, and was soon sent to the Ministries of Finance and Internal Affairs. While other provincial administrative boards put off equipping a press in 1830, the Iaroslavl board enthusiastically bought two new presses and renovated an older press it already owned. In addition to the 230 copies of the paper that were required to be sent to administrative offices throughout the province, 315 private organizations or persons subscribed to the paper. This response suggests that Iaroslavl continued to be unusually receptive to print culture. Among the subscribers were "nobles, merchants, townspeople, and even 21 peasants." 48 Like later vedomosti, it published information on industry, trade, and agriculture, with a special interest in markets and fairs. Publication of the prices of various goods continued the tradition established by Derzhavin. Much of the paper consisted of government orders and official announcements, including the sale of estates and serfs. In 1831, the newspaper published information about a peasant rebellion, even though this was among the forbidden topics dealing with politics and state secrets. ${ }^{49}$ 
The decision to create the unofficial section was a contested one. Minister of Finance Kankrin was the most powerful proponent of including as much local material as possible, while Minister of Internal Affairs A. A. Zakrevskii was resistant. In a letter to Zakrevskii in July 1831, Kankrin complained that the material from the central government in the Iaroslavl Provincial Newspaper "is crowding out the most useful articles, such as, for instance, domestic news, local information and so on." Instead, Kankrin stated, topics unrelated to Iaroslavl such as "the hiring and firing of rural police chiefs in all the Western provinces and in Belostock region" were squeezing out the most important local news. Zakrevskii's marginal note said not to reply and to send the letter to the archive. Instead of a direct reply, Zakrevskii gained Nicholas I's permission to reprimand the paper for publishing items unrelated to Iaroslavl in the official section, including "on measures of preventing exiled prisoners from new escapes by assigning them work that does not include the use of carts" and "on the sentencing of the Orlov provincial board for illegal actions in the affair of the peasant woman Grigor'eva." ${ }^{50}$ This struggle ultimately resulted in Kankrin's victory, however. The Iaroslavl paper introduced the division of the official from the unofficial section that became the model for later papers. With the support of Kankrin, it seems that the paper was able to emphasize more local material than would have been possible under Zakrevskii alone.

The decision to increase the amount of local material in the newspaper was taken as early as 1833, judging by the MVD's correspondence with the Vladimir provincial administration. According to a March 27, 1833, letter from Minister Bludov to the governor of Vladimir, S. S. Lanskoi, the provincial newspapers were to carry the orders of the central provincial administration to district (uezd), town, and subdistrict (volost') boards. The newspaper also needed to include "calls for elections to noble and town corporations; sentences for disturbances, negligence and omissions, when the provincial board decides to make them public; job announcements and information on the transfers, firing, or awards of bureaucrats; news about extraordinary occurrences in the provinces; and anything else, such as orders or information, that need to go out to every position and person." 51

The Iaroslavl experiment shaped later legislation. When the Iaroslavl paper created a separate unofficial section, it elevated the unofficial section to the level of the official section; each section was a self-contained whole, including separate pagination. While the 1830 statute spoke of one newspaper, the 1837 statute establishing the provincial newspapers discussed two separate papers and allowed subscribers to choose to receive only the unofficial section. From the Iaroslavl paper on, the unofficial sections were mainly composed of articles about their regions. Merchants were prominent among 
newspaper correspondents in Iaroslavl and later in Vladimir and elsewhere. In 1838, officials in other provinces requested copies of the Iaroslavl paper from its governor to assist with establishing their own papers, so it influenced other papers directly. ${ }^{52}$

In 1837, Nicholas I approved a statute mandating the creation of provincial newspapers in forty-two provinces, mainly in European Russia and Ukraine. Notably absent were the Siberian provinces, despite their strong manuscript and print culture. ${ }^{53}$ The structure of the paper was simplified; rather than four sections, there were only two: official and unofficial. For both sections, the 1837 statute called for more local material than the 1830 one. While the 1830 papers were to include Senate edicts and other central legislation, the text of the 1837 statute read, "the provincial newspapers will in no circumstances reprint edicts, statutes, and announcements included in the newspapers published by the Senate.” Instead of central orders, the official section would publish orders and edicts from the provincial governor and provincial board dealing with fugitives from justice, calls for elections of noble or town corporations, the setting of taxes, and invitations for bids for public contracts, and would include "announcements on the removal or resignation of any civil servants and their being brought to trial, if it is seen to be necessary to make this public." Moreover, the official section was to give a substantial amount of information on provincial, district, and subdistrict budgets, including incomes and expenses, and the allocation of taxes, material which had not previously been made public. It would be less surprising if only government officials were allowed to subscribe; instead, the statute specifically stated that it would "be sold to all who wished to subscribe." ${ }^{4}$ This directive was followed immediately in Vladimir and elsewhere, but in Tambov, private individuals were not allowed to subscribe until $1844 .{ }^{55}$ Local practices varied even if the law demanded uniformity.

The intended audience of the official section included provincial and district judges, ecclesiastical offices, local police and governing boards, and marshals of the nobility. ${ }^{56}$ The copies of the Kursk Provincial Newspaper preserved in the Russian State Library in Moscow show that the official section was heavily used. One town council made many handwritten notes on how the published orders and laws would be applied. For example, in the February 5, 1838 issue of the official section, the twenty-two rules "on the tracking down of landed estates or capital" had detailed, handwritten notes opposite each point. To facilitate this, the Kursk official section was printed with the right-hand column blank for notes. ${ }^{57}$ The Dmitrov and Arkhangel'sk town magistrates as well as the Bessarabian regional board (pravlenie) also took detailed notes on local practices of tracking down estates in parallel with the official rules, thus creating an archive of local governmental practices for future bureaucrats and historians. ${ }^{58}$ 
Following Kankrin's interest in economic news, the 1837 program for the unofficial section emphasized the current economic state of the province. It called for news of " 1 ) extraordinary events in the province, 2) market prices of various goods, 3 ) the exchange rate of gold and silver, 4) the condition of state and private factories, 5) the granting of patents and other privileges and the establishment of corporations, 6) the means of improving agriculture and household management, 7) the condition of the harvest, 8) the weather, 9) fairs, 10) the main markets and trading in the province, 11) the condition of river transportation in the province, 12) the opening of all kinds of educational establishments in the province.” History and archaeology were less emphasized: the program ended by allowing articles "13) on the discovery of old money or other antiquities in the province, 14) extraordinary natural occurrences, 15) various interesting historical events, 16) obituaries of persons deserving of general attention," along with private announcements. ${ }^{59}$

The creation of the unofficial section was a response to local experience. Over time, it expanded to cover nearly all nonpolitical aspects of provincial life. Because serfdom was also an economic system, some economic news could be seen as a comment on serfdom. Several newspapers were willing to make such veiled criticisms. However, not all newspapers were interested in doing so, as many editors were more focused on finding an audience and chronicling local events than in criticizing the center.

\section{Starting Production and Finding an Audience}

Due to the government's desire to have its edicts reach the largest audience possible, it insisted on a relatively low-priced newspaper. This led both to a diverse readership that reached beyond the nobility and to problems with financing the newspaper at the local level. Nobles were not in control of the Vladimir newspaper, as most refused to have anything to do with it, thus creating a vacuum that was soon filled by other estates. Merchants, clergy, stewards, and peasants all were published in the newspaper at one time or another, creating a print community that cut across estate boundaries.

Lack of solid financial support, however, meant that the provincial newspapers faced immediate obstacles, many of which were already evident in the original experiment in Iaroslavl. The desire of the central government to increase access to official information conflicted with their unwillingness to subsidize the papers, forcing provincial administrations to raise the money where they could. The 1830 statute was unclear on which government bodies would receive the paper for free and which would have to pay. The price was set at no more than ten rubles. ${ }^{60}$ In July 
1831, Kankrin received a report from the Iaroslavl treasury complaining of the actions of the editor of the local newspaper. After the editor asked the provincial treasury to disburse 300 rubles to the newspaper, as specified by the 1830 statute, he then took advantage of a loophole in the law to demand that each of the subdistrict treasuries also send him 300 rubles. The treasury also accused him of forcing all the lower-level agencies, such as the subdistrict governing boards, the Demidov School, and others to pay 10 rubles to receive the paper. ${ }^{61}$

Many provincial governing boards did not have a printing press, and acquiring one was very expensive, as was the type. The MVD was only willing to lend the money, arguing that subscriptions would soon cover the cost. In the case of Vladimir Province, the MVD loaned the administration 3402 rubles and 85 kopecks to buy new fonts and a new printing press, but it did not provide any regular support for the newspaper. Instead, land duties, taken mainly from the peasants, were to support the printing press. ${ }^{62}$ However, these revenues were also earmarked for other recipients and were not always available to the press.

In Vladimir Province, the 1833 order to begin publishing a local newspaper triggered an investigation of the Vladimir printing press by the next year. Governor Lanskoi, who headed the investigation, found that the provincial board press, under the direction of Il'ya Smirnov, had been operating as an independent entity. The Vladimir treasury paid Smirnov directly for printing, rather than paying the provincial board. In addition, no records were kept during Smirnov's tenure because he had made all the decisions himself and did not report to the provincial board. Smirnov argued that the board never provided more than the insufficient sum of 300 rubles a year, and that therefore he had to deal directly with other government organs, such as the treasury, if the press was to remain solvent. ${ }^{63}$ Smirnov lost his position, and from 1835 to 1837 the governor and the provincial board oversaw the needed purchases, including the new printing press, furniture, a new room, and other materials. From 1837 on, the press kept records, made reports, and in general became a bureaucratic unit of the provincial board. ${ }^{64}$ The difficulties in Vladimir were probably not unique and suggest one reason for the delay between the 1830 pilot project and the 1837 codification of the new program for the provincial newspapers.

In October 1837, the Vladimir governing board decided it needed 2280 rubles from subscriptions in order to cover the costs of bringing in a new printer from Moscow and renovating the press. ${ }^{65}$ The subscription money for the first year totaled 2574 rubles, suggesting that, at least at first, the societal response was higher than expected. ${ }^{66}$ However, the board had increased the subscription amounts beyond what the government was willing to allow, as we will see below. In addition, it estimated 
that private announcements would bring in an additional 300 rubles a year. ${ }^{67}$ The law mandated such announcements when selling property, making them a reliable source of income. These announcements were required not just for the sale of nobles' property, but also for that of state peasants and artisans, usually for debts. ${ }^{68}$ The central government was not willing to allow advertisements for the sale of serfs without land; in 1840 the Simbirsk paper was chastised for running such an announcement. ${ }^{69}$ However, in 1841, the Voronezh paper ran an announcement that "Cavalry Captain N. Maksimovich wants to sell, for a reasonable price, his serf, trained to domestic service and capable of being a coachman." ${ }^{70}$ An acceptable and very common type of announcement was a listing of runaway serfs.

The 1837 statute did not clearly fix the price of the newspaper or designate which government bodies would have to pay to receive it. This caused a good deal of confusion and conflict. As in Iaroslavl, the Vladimir central administration decided to force low-level government bodies such as the subdistrict treasuries to subscribe to the official paper. They also increased the subscription price to ten rubles for the official section, plus two rubles for shipping. The unofficial section cost an additional five rubles. ${ }^{71}$ On December 28, 1837, the MVD wrote the Vladimir board, stating that the cost of the paper was set by the 1830 statute at ten rubles and could not be increased..$^{72}$ The board temporarily ignored this ruling; although some governmental bodies could subscribe to both sections for ten rubles if they knew to ask for it, over the course of 1838, the private subscribers whose money was collected after the MVD ruling paid at the higher rate. By November 2, 1838, nearly a year after receiving the circular, the board ruled that the total amount for a subscription to both the official and unofficial section would be ten rubles; the official section alone would cost seven rubles, while the unofficial would cost three. ${ }^{73}$

The relatively low cost of the subscription made the paper accessible to a broad section of the provincial population, in which nobles did not play the dominant role. An analysis of the Vladimir Provincial Newspaper unofficial section's subscription lists for 1838 gives a sense of the local audience for the paper. ${ }^{74}$ Merchants made up the largest percentage of subscribers (82 out of 263, or 31 percent). Nobles and members of the police came next, each with 44 subscriptions (17 percent). An analysis of the social composition of the police force in Vladimir Province in 1834 showed that only 13 percent were from the nobility, 27 percent were from the clergy, and the remaining 60 percent were clerks or children of clerks either without a rank or in the lowest six ranks. ${ }^{75}$ Thus, the police cannot be considered as mainly noble. The police were required to sign up subscribers and so probably felt pressure to subscribe themselves. Thirty-six stewards subscribed, accounting for 14 percent of the total. 
This group was heterogeneous in composition, including foreigners, peasants, and some low-ranking bureaucrats. Eleven official institutions subscribed, comprising 4 percent of the total. Eight percent of the total, or 21 individuals, could not be identified by estate; even if all of these are assumed to be nobles, this would bring the percentage of noble subscribers up to only 25 percent, still less than the merchants. Rounding out the list were 7 peasants, 6 townspeople, 6 women, 5 subdistrict level bureaucrats and 1 priest. Thus, a wide variety of social groups subscribed to the newspaper, from nobles down to and including peasants.

The predominance of merchants among the subscribers is also evident in the geographical breakdown of the subscription money collected. ${ }^{76}$ Nearly a quarter (625 of 2574 rubles, or 24 percent) of the money came from Shuia District. This district included Ivanovo, which was becoming a purely industrial town second only to Moscow in the cotton weaving industry. ${ }^{77}$ The next largest amount (388 rubles, or 15 percent) came from Melenki district, an important production and distribution center of the linen industry. ${ }^{78}$ Next came the trading town of Pokrov, located on the road between Moscow and Vladimir (10 percent), then the market gardening center of Suzdal (9 percent). Those regions less centrally located and less involved in trade and industry accounted for a smaller percentage of the subscription money. In other words, Kankrin's vision of the newspaper's audience as coming from economically vibrant areas was borne out in the case of Vladimir.

Although nobles did take part in the newspaper, they were not the dominant force (to the chagrin of several of them); instead, a relatively broad cross section of provincial society collaborated with the paper. According to the Vladimir editor, Konstantin Nikitich Tikhonravov, the estate composition of authors whose works were published in the Vladimir Provincial Newspaper from 1838 to 1868 was as follows: "42 bureaucrats, 26 clergymen, 18 nobles, 16 merchants, six peasants, three townspeople, eight teachers, eight university students and seminarians and two gymnasium students."79 This account actually deemphasizes the role of the clerical estate, as many of the bureaucrats were seminary graduates. These individuals can only be definitively identified by biographical work because they were often identified by their rank, not their estate. Nearly all the editors of the Vladimir paper were drawn from this group. Enterprising nobles and textile magnates from Ivanovo and Shuia were the main sources of correspondents from these estates. Peasants also participated: in 1850 and 1852, two peasants published different sixteenth-century documents dealing with the estates of Prince D. M. Pozharskii in the Vladimir region. ${ }^{80}$ In short, the government's insistence on a relatively low-priced newspaper meant that subscribers were not limited to the nobility. In addition, the practice of 
oral, communal reading was still alive during this time, so many more heard the newspaper than subscribed to it directly. ${ }^{81}$

While several authors hoped that the nobles would take the lead in participating in the newspaper, it was the clergy who proved the most responsive. In contrast to nonresident nobles, priests lived in the villages and also kept the village "archive" of metrical books, lists of donations to the church, and descriptions of the church's contents, providing them with a rich source of information. In 1839, Alexander Herzen, who was editing the Vladimir newspaper during his exile, wrote that "aside from landlords, no one can tell the editor about the economic details of agriculture and the everyday life of the peasantry." ${ }^{22}$ However, no nobles responded to Herzen's call. ${ }^{83} \mathrm{~A}$ similar dynamic appeared with the attempt by a local noble, Andrei Chikhachev, to interest the nobility in collecting information on the region; after a period of no response, he began to call on the clergy, with much better luck. Although only one priest subscribed in 1839, more than a decade later, editors routinely called on the clergy to send information. Priests replied with histories of their villages and aspects of church history. ${ }^{84}$ In 1852, the Vladimir newspaper published a letter from I. Valedinskii, who remarked that "for a thinking person it is especially fascinating to study that corner in which he lives, its similarity and differences with other regions, relations with them and with the whole country." ${ }^{55}$ Several priests responded with letters describing their villages, one noting, "as the soul is in the body, so the church is in the village." 86 Thus, multiple attempts to claim the vedomosti as a forum for the nobility collapsed in the face of noble disinterest and the willingness of other estates to take part.

\section{Central and Local Programs of the Unofficial Section}

The editors of the unofficial section of the vedomosti played the crucial role in encouraging a network of authors and readers that cut across estate lines. Surprisingly, given the controlling nature of Nicholas's reign, these editors had a good deal of latitude in developing their own programs, thus determining the slant of the newspaper and the intended audience. This was particularly marked in provinces with a strong print and manuscript culture; in such cases, the government program was modified to fit with local interests. After 1848, however, censorship was intensified. The 1837 government program emphasized commercial knowledge such as fairs and market prices; it appealed to merchants and landlords engaged in market agriculture. In contrast, the editorial programs that began to be developed at the local level emphasized the systematic study of the province's past and present. An emerging group of merchants and bureaucrats from the clerical estate contributed their work toward the larger study of the province as an economic, intellectual, cultural and moral whole. 
The editors of the unofficial section defined the role of the newspaper in society by printing a program that outlined the content of their paper. In the legal documents establishing the vedomosti in 1830, the editor's duties were clerical; he was to revise the announcements sent from government organs and from individuals, to make sure that they were not against the law, to ensure that their printed form was the same as in manuscript, and to keep track of the money brought in by private announcements. ${ }^{87}$ The 1837 statute did not add to the editor's functions. Many newspaper editors were clerks who did their work superficially and saw no need to create extra work for themselves by writing articles for the unofficial section. Some, however, were very active writers and encouraged others to send in articles of local interest. These editors were assisted by the vaguely defined role of the unofficial section and were influenced by preexisting traditions of print culture.

The Astrakhan newspaper is a good example of the influence of a preexisting print culture. This multiethnic trading center on the lower Volga was part of the Kazan Educational District and already had several periodicals in the 1810s that introduced themes later developed by the vedomosti. Teachers at the Astrakhan gymnasium began to study and publicize the different peoples of the Russian Empire and beyond. The German teacher, Joseph von Weishofen, began publication of Astrakhan's first newspaper, Eastern News (Vostochnye izvestiia) in 1813. His second, more restricted, program stated that the newspaper would publish news on "first, the town of Astrakhan itself; second, on the lands composing the provinces of Astrakhan and Kazan, and parts of Taurida, the lands of the Don and Black Sea Cossacks, Georgia, the lands of the Caucasian mountain peoples, the southern part of Saratov and Orenburg provinces; third, on the lands inhabited by Kalmyks, Karakalpaks and Turkmen; fourth, on the relations of Russia with Eastern countries, such as Khiva, small and large Bukhara, Persia, Turkey, and if it is possible, Arabia, Eastern India, and Tibet." ${ }^{88}$ The newspaper did publish news from the region until Weishofen's death in 1816. In that same year, the music teacher at the Astrakhan gymnasium, Ivan Dobrovolskii, began publication of the first lithographed journal in the Russian Empire-the Asiatic Musical Journal (Aziatskii muzykal'nyi zhurnal). As Dobrovolskii wrote in 1816, the journal was to publish "various Armenian, Persian, Indian, mountaineer [gorskie], Kyrgyz, Chechen, Georgian, Tatar, Kalmyk, Khivan and Bukharan, Circassian, Kabardian, Kazakh, Nogai, Lezgin and Turkmen songs and dances, which will be arranged for the piano." ${ }^{99}$ Over the course of the next two years, songs were published in Kalmyk, Tatar, and Armenian, among other languages.

Similarly, M. S. Rybushkin, editor of the Astrakhan Provincial Newspaper, wrote in 1838 that the newspaper would print "essays on the peoples [narodov] of 
various tribes who live in Astrakhan province, such as: Armenians, Kalmyks, Tatars, Persians, Indians, Bukharins, Turkmen, Khivans and Kyrgyz, with historical descriptions of their activities, everyday life, traditions, legends, costume, songs, dialects, architecture and economics, with description of religious rituals, holidays, etc., notable for their originality." 90 This statement had clear predecessors in earlier Astrakhan periodicals.

Other papers interested in the study of non-Russian peoples included the Kazan Provincial Newspaper, which published extensively on the topic, particularly after 1852, when Professor I. N. Berezin, a famous Orientalist at Kazan University, was named editor. The number of articles on the history of Kazan and the Tatars noticeably increased because Berezin was an expert on the history of the Volga Bulgars. ${ }^{91}$ Similarly, the Orenburg Provincial Newspaper published several articles by another Orientalist, V. V. Vel'iaminov-Zernov, on such topics as the history of the Kyrgyz and on sources for the study of the Orenburg region..$^{92}$ In 1853, the Orenburg paper was reprimanded for publishing an article by V. V. Zav'ialov that made "disapproving allusions to Russian military expeditions to the Kyrgyz steppe.”93

Some editors extended the scope of the newspapers' coverage by emphasizing different subjects than those found in the law. For example, the Astrakhan program stated it would include material "on the building of churches, including chapels, vestries, annual holidays of each church, holiday processions of the cross, and so on." ${ }^{44}$ This was without precedent in the law code, showing the latitude editors had in establishing their programs. The newspapers were not supposed to cover religious topics. Instead, from 1860, when the Iaroslavl diocese was the first to publish its own newspaper, separate newspapers (eparkhial'nye vedomosti) under the control of the Synod dealt with religion. ${ }^{95}$ Regardless, the Astrakhan paper published not only many descriptions of churches - they were common in other papers because they could fit under the rubric "discovery of antiquities"- but also statistics on religious affiliation, biographies of Astrakhan bishops, and a defense of Armenians against the charge of paganism. ${ }^{96}$

Editors could use the government program as cover for their own interests. In 1838, Herzen wrote in his program for the Vladimir Provincial Newspaper that "the goal of the supplement [i.e., the unofficial section] is not literary but statistical." "97 Herzen drew upon the emerging reorientation of statistics away from the needs of the state and toward the needs of the people. "The unofficial part of the newspaper, along with the provincial statistical committees," he wrote, "must open the interior life of every part of our motherland, make known everyday life [byt] and the means of subsistence, make public [dat' glasnost'] all the particularities of one's region, including extraordinary events." ${ }^{88}$ This program emphasized the condition of the 
people [narod] much more than the 1837 statute. "The editors will be particularly glad to receive any information 1) on the everyday life of the people. The peasants of Vladimir Province have very many peculiarities, in their internal life as in their very activities, and every peculiarity is a precious fact . . . for time, little by little, is erasing these peculiarities." ${ }^{\text {99 }}$ Herzen was particularly interested in comparisons of state and landlord serfs and improvements in agriculture in order to find "the specific reasons for the improvement and decline of villages." ${ }^{100}$ This is an example of the use of a plank of the government-approved program ("the improvement of agriculture") for very different purposes than the government had intended.

In 1845, a new program for the provincial newspapers was promulgated that increased the importance of history and archeology and introduced ethnography as an approved topic. The new program stated that the unofficial section "may include news and articles of all types which deal, more or less, with the locality [mestnost']: geographical, topographical, historical, archaeological, statistical, ethnographic, etc., information," only then listing market prices, factories, patents, and river traffic. ${ }^{101}$ This program was much more systematic than the earlier one. The new statute's focus was on studying the locale as an organic whole, rather than on disseminating useful facts about the local economy.

Ethnography was the most important addition to the 1845 statute. It had not been listed in the old statute, although the Iaroslavl paper, followed by many others, had published articles with ethnographic information. From 1831, S. A. Serebrennikov, a Iaroslavl merchant, was an active contributor; he published "around 60 articles and historical documents about the establishment of and the trading links of Iaroslavl, ethnographic notes about wedding rites in the province."102 The introduction of ethnography in 1845 and the articulation of a more organic view of the scientific study of the provinces was part of a trend within the Ministry of Internal Affairs and the Russian Geographical Society (RGO), established in 1845. Leading statisticians in the MVD such as K. I. Arsen'ev were also founding members of the RGO. ${ }^{103}$ There was a close link between provincial statistical societies and the provincial newspapers. The needs of statistical collection in the service of the empire and the people strongly influenced the 1845 program. The RGO had a particular interest in ethnography, which helps to explain its inclusion in the 1845 program. ${ }^{104}$ This inclusion was also partly a concession to the continuing interest of editors and correspondents in the condition of the people. Ethnographic articles often ran afoul of the censors, particularly after 1848 because ethnography included information on the life of the peasants and veiled criticisms of serfdom or religion. Ethnography provided a means for individuals from different estates to work together to study their locality, and, through it, the empire. ${ }^{105}$ 
Some papers focused more heavily on ethnography than others. The Vladimir newspaper rarely published ethnography, as its longtime editor, K. N. Tikhonravov and its main correspondents did not focus on it. ${ }^{106}$ In contrast, members of the Voronezh circle of N. I. Vtorov published extensively in the local newspaper, mainly on ethnography and old archival documents. Vtorov had been the editor of the Kazan Provincial Newspaper in the early 1840s, where he had focused much attention on the ethnography of the non-Russian peoples of the region. ${ }^{107}$ Due to space problems (the editorial office was located in a room that "served as accommodations for prisoners while they were being supplied with clothes before being sent into exile") the editorial board often met at Vtorov's house and discussions included members of his circle. ${ }^{108}$ This group had contacts with the lexicographer V. I. Dal' and the folklorist A. N. Afanas'ev, who was born in Voronezh. In 1847, A. S. Afanas'ev, the editor of the Voronezh Provincial Newspaper, wrote in his first editorial that "all that is curious and remarkable in historical relations and all that is specific and characteristic in folk [narodnykh] traditions and beliefs - all must take the pride of place in the provincial newspaper, which is an inexpensive publication, and, it follows, accessible to all." 109

Afanas'ev even introduced a new section entitled "folk reading," which provided useful information on the family and everyday life as well as folklore materials in an easy-to-read popular style. ${ }^{110}$ This should not be seen as an unrealistic plan, as both the Iaroslavl and the Vladimir subscriber lists included some peasants, usually state peasants. In 1838, the Viatka Provincial Newspaper had published a crown peasant's article, and it later introduced a section entitled "Folk Health" (Narodnoe zdorov'e) that aimed to spread useful medical information through the common people; in 1848 and 1849, the Viatka paper even brought in new payment options to make it more accessible. ${ }^{111}$

The newspapers were originally placed under the censorship of the governors. In 1838, a secret MVD circular instructed the governors to make sure not to publish "news that might wrongly bring about anxiety in people's minds, or that is based on absurd or indecent rumors, such as, for instance, about disobedience being shown to landlords or other legitimate authorities, of attempts by peasants or house serfs to kill their masters, of cruel treatment of peasants by landlords." 112 Even so, such material was sometimes published, with the argument that it fell under "extraordinary events in the province.” Until 1848, censorship was often rather lax. It took several months for the printed newspapers to be sent to the main censorship committee in St. Petersburg; even if the central censors objected, the material had already been published. An April 1847 letter from I. E. Protopopov, editor of the Vladimir newspaper, to the future editor, Tikhonravov, suggests that the severity of censorship under the 
governor could vary significantly. "When, in the absence of [Vice-governor P. S.] Kozhin, [Governor] Kurut censored the paper, I was always free and easy, but when Kozhin censored it, I acted cautiously," Protopopov wrote. ${ }^{113}$ Some censors were rather broadminded. For example, the Saratov censor, Director of Saratov Schools Meier, passed folk songs, including one on Stenka Razin, which made Nicholas I so angry he ordered Meier to be sent to a detention cell for a month and then removed as censor. In 1848, central censors chastised the Kazan Provincial Newspaper for publishing a folk song referring to bandits as "good people." 114

In 1850, concern over challenges to religion triggered a harsher censorship regime for the vedomosti. In that year, the Kursk newspaper published an article entitled "On the Fossils of Kursk Province," in which, according to the main censorship committee, "the formation of our planet and the very appearance on earth of humans was portrayed and explained according to the understanding of several geologists, completely at odds with the cosmology of Moses in the Bible." 115 As a result, the vedomosti were placed under regular censorship. In those areas without censorship committees, university professors or schoolteachers censored the paper. ${ }^{116}$ Also in the early 1850s, the Orenburg Provincial Newspaper was reprimanded for publishing "Examples of Superstitions Found among Russians from Pagan Times," which the censor called contrary to Christian teachings. ${ }^{117}$ In 1853, Nicholas I forbade the publication of folklore that "is not the least useful to preserve in the people's memory via print." ${ }^{118}$ For instance, in 1853, the Kursk Provincial Newspaper was reprimanded for publishing impious folk sayings that "destroy good morals and may give cause for superficial or false opinions on holy matters." One riddle stated: "He was born and not baptized/ Died, and was not saved/ and yet was a God bearer." The answer was "a donkey." 119 Through the editors, the provincial newspapers attracted a wide spectrum of the literate public whose interests sometimes extended beyond the bounds of the limits set by the government. The running battle between censors and periodicals was not limited to the capitals but occurred in the provinces as well.

\section{Local Writing: Responses to the Unofficial Section in Vladimir Province}

An editor could control his newspaper's program, but without the creation of a print community, filling up the unofficial section could be difficult. This community included the authors and their readers, both in the provinces and the capitals. The national and local print communities intersected, and as these authors became increasingly well known, their social networks extended throughout the province 
and beyond. Through the reading and exchange of both letters and articles, authors became connected to an ever-broadening community interested in the same topics. ${ }^{120}$ Different authors had varying motivations for participating in this community, depending on proclivities and social standing.

This section examines the response of three men to the unofficial section of the Vladimir Provincial Newspaper: the priest's son and newspaper editor Vasilii Dobrokhotov, the Shuia merchant Vladimir Borisov, and the Slavophile noble Andrei Chikhachev. The last two were among the most frequent contributors to the newspaper in its early decades. All three were engaged in a larger print community, and the Vladimir newspaper formed a bridge between that community and their local surroundings. Dobrokhotov wrote for M. P. Pogodin's journal, The Muscovite; the Vladimir paper provided a forum to announce his publications, and, later, under the new, more scholarly editorship of Konstantin Tikhonravov, to denounce Dobrokhotov's works. Borisov also had connections with Pogodin and with the Moscow Society of Russian History and Antiquity, which published his articles, often reprints from the Vladimir paper. Finally, Chikhachev was also part of the national print community through the journals of the Ministry of State Domains, even at one point conducting a polemic with the Westernizer N. P. Ogarev. ${ }^{121}$ While Dobrokhotov and Borisov wrote or attempted to write scholarly articles on history and antiquities, Chikhachev was quite different, standing as he did not for scholarship, but for the transmission of basic values from one generation to the next with minimum loss. The Vladimir paper brought these individuals together in a way that their national print communities would not have been able to, as their audiences were too different.

The main participants in the newspaper were priests' sons and merchants, not nobles. All the pre-reform editors of the paper's unofficial section were seminary graduates, except Herzen. The factory owners of Ivanovo and Shuia composed another socially receptive group in Vladimir Province. These merchants, either Old Believers or converted Old Believers, still had a strong tradition of literacy and a reverence for old manuscripts, and they were equipped to write on both economic and historical topics. The Vladimir bureaucrats and the Ivanovo merchants formed the core of the social network around the newspaper. Most nobles came to the city only for the winter social season rather than living there year round, so the clerical estate was the best-educated estate with a strong tie to the rural communities. ${ }^{122}$ Chikhachev, partly responding to the marginalization of the nobility in the newspaper and their lack of response to the newspaper's program, exhorted nobles to live throughout the year on their estates and emphasized the importance of the village and manor as the center of rural life, contrasting it to the empty pleasures of the city. 
The Vladimir seminary produced a steady stream of well-educated yet socially inferior graduates, many of whom went into the bureaucracy. Despite the major problems of the seminary, which included corporal punishment, rote learning, and poor facilities, it still provided a good education. The seminary's curriculum emphasized "religion, service to the populace, the humanities, and Russian culture." 123 It taught writing in Russian and Latin, logic, modern languages, and poetry, which was publicly declaimed along with prose compositions at May "recreations" and public disputes. This training was especially conducive to preparing writers and editors. One former seminarian from Moscow wrote, "I definitely came away with little knowledge [from the seminary] ... [but] I learned to write freely and with animation, and my thought was rather well developed." 124 The seminary put "a great accent on Russian national culture. . . . Neither Russian Church history nor a distinct course in Russian history were taught at the gymnasium." 125 Vladimir's gymnasium served mainly the local nobles and emphasized science as well as classical learning. This training and the archival tradition of the Russian clergy (recording births, deaths, etc.) meant that seminary graduates who entered the bureaucracy were unusually receptive to the historical aspect of the unofficial section's program. ${ }^{126}$

In 1849, the governor named Vasilii Dobrokhotov, born in 1814 to the archpriest of the main Vladimir cathedral, as editor of the unofficial and official sections of the Vladimir Provincial Newspaper. He held this position until 1853, when he was replaced as the editor of the unofficial section but remained the editor of the official section. He retired in 1854 due to ill health and died in $1856 .{ }^{127}$

Instead of following the 1845 government program's emphasis on systematic study of the region, Dobrokhotov was strongly attracted to the feuilleton, a literary genre originating in France in the first decade of the nineteenth century. It then became popular in Russia, where it retained its focus on theater and town life in general, written in a lively way with an artistic attitude toward facts. ${ }^{128}$ In 1849, Dobrokhotov wrote that the unofficial part of the newspaper was "our little feuilleton" and its general goal was to "be a curious and useful collection of information on Vladimir Province." 129 The provincial newspapers, he said, "include a large reserve of material for the natural scientist, the medical man, the agronomist and especially for the archaeologist, the historian and, one may say, the poet." ${ }^{130}$ The feuilleton emphasized the subjective experience of the author and made no attempt at scientific objectivity, for a poet's inspiration need not have the same degree of accuracy as the scientist's facts. Indeed, Dobrokhotov was by his nature and literary style a feuilletonist who also wrote about history and archeology and was more than once criticized for his lack of accuracy. 
Dobrokhotov had been named editor of the newspaper on the strength of his first book, Monuments of Antiquity in Vladimir, elegantly published at the Moscow University Press in 1849. In that year, Pogodin wrote a generally positive review in The Muscovite (Moskvitianin) but also cautioned that "there is more than a little tar added to the honey in this barrel" and then listed typographical and factual errors. ${ }^{131}$ "Vladimir is lucky to have so many active people and lovers of antiquity," he wrote; "with special pleasure we constantly read articles in that provincial newspaper by Protopopov, Tikhonravov, and Dobrokhotov. If these workers had the means, the history of the Vladimir principality would be so much enriched that the historian would be left with nothing to wish for." ${ }^{132}$ In 1853, Dobrokhotov published a new book, The Ancient Town and Monastery of Bogoliubovo and Its Surroundings. Although Pogodin liked the work well enough to successfully sponsor Dobrokhotov as a new member of the Society of Russian History and Antiquity, Tikhonravov wrote a devastating review of the book in The Muscovite attacking Dobrokhotov's main propositions. ${ }^{133}$ The review brought into question Dobrokhotov's accuracy as a scholar and implied that Tikhonravov would have done a better job.

Dobrokhotov's tone, perhaps even more than his scholarship, raised hackles. His writings were often ironic and cutting, showing the sensitivity of a highly educated man to his socially inferior position. The nobility excluded seminarians from a place in society, which was defined as an entirely noble sphere. ${ }^{134}$ Dobrokhotov wrote several feuilletons rejecting the "boulevard" in favor of the lower-class "folk walk" (gulian'e). The folk walk was a holiday in which peasants and townspeople would stroll in pleasant natural surroundings. "The boulevard,” Dobrokhotov wrote, "is a place where everyone comes for show; it is a center for customary walks in the town. But here they walk decorously, one may say deliberately, with calculation. It is completely different in the folk walk outside of town, where they walk in the ploughed field; where if you're not against a shot glass, take a shot glass, or even a bigger glass; where the young man, with naive openness, may talk with his sweetheart; where a tired fat man, without ceremony, stretches out in the shade where it's cooler, with the sounds of the violin or horn, and there is both shade and beer."135

Dobrokhotov evinces an even sharper feeling of resentment toward the Europeanized and wealthy elite in another article. "With the end of summer or in the first autumn month, when the walks in the surrounding countryside and on the boulevard have ended and with them the happy dancing evenings, what remains to us, so that in our free time we don't sit at home in crushing boredom? Theater? But it is not open every day. Salons? But they are too exclusive. Literary evenings, it seems, don't exist here, and musical ones are all the same. Play cards? What, already with 
the cards? Yes, and anyway these amusements are more accessible to famous or rich people." ${ }^{36}$ The key words here are "too exclusive.” Dobrokhotov, like other highly educated priests' sons, keenly felt his exclusion from upper society.

Dobrokhotov also rejected the supposedly superior morality of the upper classes of society in a passage describing the petty traders in Vladimir's secondhand market: "But what is to be done, when God, in his wisdom and foresight, has given one person talents, another two, and another ten talents? Each reasonable person tries to earn more and more for himself ... look at the family life of several of these traders and you will see that they have their own happiness and comforts: there is a modest wife, good little children, and a well-deserved bit of bread. And how often in marble palaces does there slip in discord and family unpleasantness, while in the huts of these traders often one can see with satisfaction a quiet, peaceful family life despite poverty." ${ }^{137}$ Here, Dobrokhotov used the official discourse of family life to critique those in power.

Also striking in his work is the independent nature of the lower classes. While for many official writers, the peasants were dependent children, in Dobrokhotov's work, they lived and loved outside the supervision of higher society. This is obvious in his description of a folk walk: "High-toned people and those who conduct themselves more delicately, more modestly, absent themselves from this walk, despite the fact that this is a beautiful location and it seems it ... should attract city residents of all estates. But such is not the case. . . . First, there is the immodest folk name of the place of the walk, [second], the simple people, especially those who have drunk too much, do not conduct themselves very modestly.” Dobrokhotov described the location of the walk and asked, “Did there not stand an idol to Iarun’ or Iarilo here during antiquity? Legends tell us that young Slavic men and maids gathered before it and celebrated with songs and dances of a type that would seem frenzied to a Christian age."138 Dobrokhotov's footnote identifying Iarun' as the same god as the Greeks' Priapus would have made it clear to the educated reader just what kind of frenzy he was writing about.

In addition to favorably comparing the lower classes to the upper, Dobrokhotov also tried his hand at defining the various types found among the people. The "physiognomic feuilleton" was quite popular at the time, as it fixed groups of people within a classificatory scheme at a time of great mobility. Physiognomy argued that one could read the character of a person in his or her face, which allowed the stroller to act like a social scientist. In his most significant physiognomic feuilleton, on Vladimir's secondhand market, he described the traders as "the poor of various estates," "the lowest classes of society," and as the "dark people" (chernyi narod). He consistently mixed high and low subjects in this feuilleton. Instead of patriotic 
expressions, we get the following: “And between these market women you can nearly always see a veteran of practically the Napoleonic Wars, who at one time braved the fire of the enemy, and now sits among little boxes, shaving brushes, small scissors, boots, galoshes, and even women's clothes, or more accurately, rags." 139 In contrast, official discussion of the Napoleonic Wars mentioned the brave self-sacrifice of the folk. Dobrokhotov also described a trader whose booth was so small and filled with goods that he was unable to turn around, and so stood there "like a statue in a niche." In listing the booth's stock, Dobrokhotov noted, "there, for the lover of antiquity [liubitel'stariny] are sausages from the previous century." 140 This description would have been particularly insulting to scientifically minded people such as Borisov and Tikhonravov, who described themselves as "lovers of antiquity."

Dobrokhotov's presentation of himself was contradictory. On the one hand, he wrote feuilletons emphasizing his own subjective perceptions, while on the other, he presented himself as a scholar. ${ }^{141}$ Instead of writing about the lower classes in the scientific tradition of descriptive statistics, he did so in the subjective genre of the feuilleton. His most daring feuilletons were pointed only in his first year as editor. He was writing in 1849, during a time of heightened censorship, and it is surprising that they appeared at all. Overall, the picture that emerges from Dobrokhotov's feuilletons is of a deeply divided society in which exclusive gatherings and the coldness of marble palaces is juxtaposed with the earthy needs of the peasants. Thus, Dobrokhotov used the Vedomosti as a mirror to show society's weaknesses and foibles.

A very different tone was set by Vladimir Aleksandrovich Borisov, a Shuia merchant who wrote extensively on the history of the Shuia region and collected old documents. He was the newspaper's main correspondent for many years. Born in 1809 to an old merchant family, Borisov grew up in stable financial circumstances, as his mother owned a cotton-weaving factory. ${ }^{142}$ His relatives were Old Believers, and he was investigated several times on suspicion of still practicing the old faith. No clear evidence was found. Regardless of his true belief, Borisov was the prototype of what I call the cultural Old Believer public figure. The Old Belief encouraged literacy and trade, especially if outside the state's direct control. Cultural Old Believers were suspected of being unorthodox; however, it is possible that while they truly converted to Orthodoxy they retained the cultural orientation toward literacy and the study of pre-schism history and art. This orientation is especially clear when comparing the cultural Old Believers of Ivanovo and Shuia with the Orthodox merchants of Vladimir town. Despite their wealth, the Vladimir merchants did not participate in print culture or the newspaper, while by the 1850s, the Old Believer merchants were among the most active participants. 
Borisov's writing contains a few tantalizing hints of his attitude toward the Old Belief. Describing the view from the river Teza looking toward Shuia, Borisov invited the reader to "sit on the bank. Behind you are half-knocked over wooden crosses among birches in the Old Believer cemetery. Before you is the river, which in summer days is a blue ribbon weaving past meadows and in spring is like a big lake covering the plain on the other side. Around it are the Shuia beauties, walking in their fancy clothes. Then we drift off into such pleasant dreams, which rarely awaken in the soul of residents of the splendid capitals." ${ }^{43}$ This statement is quite remarkable, given that the censorship rarely allowed any positive mention of the Old Believers. There is a complex of meanings around this description. The Old Believer cemetery is located behind the reader, which may imply either that it refers to the past or is the foundation for the prosperity before him. Both may be true because Old Believers were the founders of the textile industry in Shuia. The fancy clothes (i.e., of storebought material) of the Shuia beauties were linked to the Old Believers through their domination of the textile industry. The cemetery itself is Russian; birches are a folk symbol of Russia. The simple wooden crosses lack the luxury of the big city, and their half-bent, half-knocked over status raise the question of how this came to be. The word cemetery (kladbishche) was also part of the name of two major Old Believer communities in Moscow, which were self-sufficient and extremely wealthy until Nicholas I led a frontal attack on them around this time. They took the name from the large Old Believer cemeteries near their communities. ${ }^{144}$ Borisov used the word staroobriadcheskii, which the Old Believers often used to describe themselves, in contrast to the official word raskol'niki (sectarians). Thus he tied together the elements of the Old Belief, natural beauty, economic wealth, and Russianness in this description. This vision of society, even if it only refers to the past triumphs of the Old Belief, strongly differed from official discourse.

Whatever his religious beliefs, Borisov engaged with the secular print community, subscribing to several journals as early as the 1820s. Between 1826 and 1827, he received the Moscow Newspaper, in which he read the minutes of the Moscow Society of Russian History and Antiquity. This, Borisov wrote, "aroused in me the first desire to study antiquities.” 145 The Moscow Society played an important role in his life by connecting him to a wider circle of people interested in history than found in Shuia. After he joined in 1835, he began to collect historical documents that were published by the society and elsewhere for the next thirty years. ${ }^{146}$ Through the society, Borisov met M. P. Pogodin, who became its secretary in $1836 .{ }^{147}$ Pogodin encouraged and organized amateur historians in the provinces to collect and publish historical material. Thus, Borisov was already prepared to write for the Vladimir 
Provincial Newspaper from its inception in 1838. In that year, the editor thanked Borisov for the "curious and very interesting materials" he had submitted. ${ }^{148}$

Borisov's interests included contemporary factory life, which he observed first hand as a merchant in Shuia. His 1847 magnum opus on factory workers, "On the Factory, Artisan, and Working Class of the People in Shuia Town and District," presented a sympathetic portrait of industry and workers. "In every street the sound of the shuttles, the wail of unwinding thread, the tapping of the printing process, the bustling of the looms' reeds and other tools, the songs of the workers are everywhere audible. To these eternal laborers, to their occupations, customs, and characteristics, to their condition under the present development of industry, we will give our attention.” He described an unabashedly vigorous, lively, and mechanized process. Defining the "factory class of people" as the twenty to twenty-five thousand workers in the factories, excluding traders and farmers, Borisov wrote that "the factory class itself is divided into several ranks, each with its own way of life [byt] and characteristics, which distinguish one from the other." He based his description on his own experience: "I know about this by my own experience, having managed one important factory for ten years.” He divided the factory class into an artisan class and a working class. When describing the artisans, he began with the printers, who formed a sort of worker aristocracy. He noted that they read the Ministry of State Domains’ journal Village Reading (Sel'skoe chtenie), and that "those who demand something more scholarly [uchenyi] read, for example, geography, history, and particularly religious books.” Shuia's printers, he said, made less money than they once did. Similarly, the engravers were paid much more before foreign skilled workers were brought in. He praised the scientific knowledge of such groups as the colorists. "Every colorist knows chemistry or chemical processes, and all are self-taught. There are scholarly colorists, but they are not our Russians [rusaki], but foreigners, receiving a huge salary in comparison with Russians."149

Borisov then went on to describe the working class, such as dyers. "There are many good, experienced, knowledgeable dyers who are no worse than many foreigners and deserve to be paid more than they are now." In addition to unwinders and washers there were boiler men of two types: the first were state peasants and cleaner; the second came from a different district and were ruder. He noted that the latter were called zhuchki, which he terms a "rather witty name in the language of the working class.” According to Dal', zhuchka is a nickname for a black dog and a name for an unskilled worker (chernorabochii) in the Vladimir dialect. ${ }^{150}$ The nickname plays on the blackness of the dog and the "blackness" of the unskilled worker, which directly translates as "black worker." Aside from this lower group of boiler men, Borisov 
excludes the simple unskilled workers as "not really fitting into the delineation of classes." ${ }^{151}$ Borisov's article was the first in Vladimir Province to present the workers as a complex group, in which even the lower rung or "working class" could be witty. The artisan class was an important and unappreciated reservoir of practical scientific knowledge in Borisov's view. The main problem was that workers were not paid enough, particularly in comparison with analogous foreign workers. Overall, for Borisov, the newspaper was an outlet for his historical and contemporary writings and served as a forum for his research into the history of Shuia. He was unapologetically drawn to the present liveliness of the city and the bustle of industry as well as to the more distant past.

In contrast, the conservative Slavophile noble Andrei Chikhachev focused on the village, not the city, and argued that rural areas should be dominated by enlightened nobles, thus ensuring both the spread of enlightenment and the continuation of the social order. For him, the newspaper served as a means to awaken local nobles to their responsibilities, and although he was not very successful he rarely flagged in his exhortations. Chikhachev was born in 1798 and served in a less-exclusive guards' regiment from 1813 to 1818. In 1818, he retired to his estate, Dorozhaevo, in Kovrov District. ${ }^{152}$ Much of his writing dealt with the proper way to run an estate. In his papers, Chikhachev left a list of Vladimir Provincial Newspaper articles he found useful. These included how-to articles such as "Preventing Insects from Eating Garden Plants." ${ }^{\prime 53}$ His interest in the newspaper went beyond simply using it for individual economic needs, however; he envisioned the paper as a means to regenerate rural Russia, or at least his small part of it. One way to achieve this aim was to increase enlightenment without disturbing the status quo. Chikhachev first wrote for the Vladimir newspaper in 1847 and for roughly a year after the 1848 revolutions he went through an extremely conservative period where he argued that only nobles could spread enlightenment. He defended enlightenment from a conservative standpoint in an 1849 article: "Never has the question of enlightenment [prosveshchenie] been so important as in the present time, when bad understanding, bad behavior, and completely false enlightenment has so fatally darkened Western Europe.”154

His goal in writing for the newspaper was to turn enlightenment away from revolutionary channels and into the peaceful and useful collection of local information. Vladimir Province had fourteen districts, one of which was Kovrov. The idea for a district handbook detailing local sights came to him "in the last days of 1848." 155 The local, as defined by the boundaries of each district, (roughly the size of an American county), was of central importance to Chikhachev. This is apparent in his many articles supporting his proposal for a handbook for the Kovrov District. 
"Enlightenment spreads curiosity and new demands through all levels of society, arouses not only the desire, but the very necessity to know more closely, clearly, and in more detail, that region in which we live, and in which our parents and ancestors lived."156 In an 1850 article, he named the handbook The District Treasurehouse and said that he hoped to receive information on, among other things, bazaars, bridges, industry, swamps, towns, lakes, roads, factories, orangeries, and postal stations. ${ }^{157} \mathrm{He}$ called on nobles to collect information for the handbook for the good of all estates. "Cold indifference ... cannot threaten our success, especially if the nobility mutually gives each other a hand in working for the general good." ${ }^{58}$ The nobles were to lead the other estates in greater knowledge of their local surroundings and, in so doing, inspire new bonds of family feeling among the various levels of society. This was one of the first proposals to create a guidebook to a district or province. By the 1860s, such handbooks (pamiatnye knizhki) were widespread. ${ }^{159}$

Beginning in 1850, he accepted the participation of other groups, such as the clergy, in gathering information, but he retained his belief that nobles should conduct the dissemination of true enlightenment within the district. By 1851, confronted with their indifference, Chikhachev was relying more and more on information provided by parish priests. Even so, he described his work as a "report to our noble family, of whom there are not many." 160 One of the few nobles who did respond to Chikhachev's call was A. A. Rozov, a Russian language teacher at the Vladimir gymnasium, who in 1851 prepared an introduction to a handbook on legends about kurgans in Kovrov District. ${ }^{161}$ In an 1851 article entitled "Journeys in Kovrov District," Chikhachev again called for help, asking landowners to travel around their district to collect information for the proposed handbook. "It might seem strange to begin to travel in one's own district, but when I remind the reader of my continuing occupation of gathering material (albeit quietly and slowly) for use in the District Handbook, then the strangeness is explained, as when one at first sees a daguerreotype from the side and then turns it directly toward oneself." ${ }^{162}$ Chikhachev recommended visiting parish churches because the priests were best equipped to know the conditions of local life. The conditions of life in the village, the morality of the peasants, and a more exact knowledge of geography were Chikhachev's main concerns in this article.

When describing the benefits of the district handbook, Chikhachev appealed to the interests of the nobility. By his account, the handbook would promote more communication between landlords in the district, allow for joint projects, simplify the sales of agricultural products, ease the orientation process for elected noble officials, and, importantly, "draw absentee landlords closer to living constantly on their estates.... Who of these owners has not lost something irreplaceable in these circumstances!”163 
Believing as he did that the city was a hotbed of vice and wrong thinking, Chikhachev's call for increased local knowledge was at least partly inspired by a desire to promote rural, patriarchal living at the expense of citified, revolutionary activities. The district was a familial space for him. Chikhachev stressed the familial nature of the tie between the nobles and the peasants in an 1849 article about the opening of a agricultural school for nobles. "I will not speak of other estates [sosloviia] in the state, but only about our landlord [estate] and the working agriculturalist [estate], so inseparable for our happiness, our children according to the word of God. These [are] ... family-tied classes." ${ }^{164}$ Chikhachev never doubted that the nobles were the head of this societal family.

For Chikhachev, the district and the family were inseparable. In his article about the provincial newspaper, he compared the situation of a poor private individual wishing to know more about his mother country (rodina) to that of "a man orphaned in infancy, curious about the smallest details of his parents. Vainly does he solicitously try to find out about them - who they were, where they lived, what they did. And if someone told him that there is a person who knew them and was esteemed by them, who would tell him about everything, would not this good young man hurry off to attentively hear about what he so very much wanted to know? Thus is it with our Newspaper. For thirteen years, with constant cordiality, it has told us about every district." 165 The district, not the nation or the empire, was the focus of Chikhachev's efforts and patriotism.

In his "Thoughts of a Rural Resident on the Provincial Newspaper," which dates to his later, less conservative period, Chikhachev presented himself, not as a nobleman, but as a "rural resident" (sel'skii zhitel'). This is a broader term that echoes the work of the eighteenth-century landlord and writer Andrei Bolotov, whose encyclopedic interests and eccentricity are mirrored in Chikhachev. In his article Chikhachev wrote: "The provincial newspaper is more useful to us village residents of middling station [sel 'skii zhitel'umerennogo sostoianiia] than it is to city dwellers." He argued against the idea that a lack of money meant a lack of ability. "As long as a good person works with love toward his occupation, he will be honored by good thinkers," he said. "A steward, clerk, gardener, beekeeper, when their work is honest and carried out with full knowledge, these are truly useful people." ${ }^{166}$ Chikhachev's hope was to mobilize the wide substratum of right-thinking people in the rural areas to work toward the common goal of more knowledge.

In an 1850 editorial, Dobrokhotov thanked Chikhachev for this article even as he emphasized its importance for groups beyond the nobility. Dobrokhotov described Chikhachev as "an experienced, hard-working landlord of our province, permanently 
living in a model corner with his well-organized estate, in useful isolation, [who] with a true and impartial view has observed the use of the Vedomosti. Every goodthinking person [blagomyshliashchii chelovek] should agree with him." Later in the same article, Dobrokhotov states that for thirteen years, the Vedomosti has "made it possible for every person able to marshal his thoughts and a pen to manifest his activity in print." 167 The concept of "the good-thinking person" was a way of formulating a social sphere in which education and mental outlook, not estate identity, were the grounds for inclusion.

Chikhachev's oft-stated identity as a resident noble meant he valued the village as more authentic than the city and therefore worthy of study. This influenced his attitude toward urbanization and industrialization. In his 1848 Vedomosti article "The Production of Cheesecloth in Kovrov District," he argued that the weaving of cheesecloth in peasant huts was "the complete antithesis of many different factory occupations, [in that] it upholds that morality of the peasants, which among industrialists is now so unreliable." With 1848 as the implied counterpoint, he described the idyllic existence of the cheesecloth weavers, describing the peasants' hand-made looms as "nationally alive [natsional'no-zhivo]" and the sound of the shuttle as "a musically-even whistle." Moreover, "the morality of the cheesecloth weaver is exemplary. And how could such a man be immoral? He, from the time he was an infant at the breast, and stood on his feet, was drawn from his mother either to his father, a weaver, or to his brother and sisters, acting as assistants." 168 This emphasis on cheesecloth production was part of a larger project of encouraging rational agriculture, including the introduction to the peasants of new dairy products in addition to sour cream and cottage cheese. The Iur'ev Agricultural Society, a group of nobles from Vladimir Province interested in market agriculture, was founded in 1854; in that year the society praised one Iur'ev noble who had introduced the production of Swiss cheese among his peasants, using a Swiss overseer. ${ }^{169}$

We can see that the newspaper did call forth a response from a group of authors that crossed estate lines. The provincial newspaper provided a broad enough forum to allow different people to put forth their own visions of its utility and meaning. For Dobrokhotov, it was a place for feuilletons and a platform for critical examination of society. For Borisov, it was an outlet for his historical work and a means to defend the merchantry. Chikhachev saw paper as a way to regenerate the noble estate, and, through it, the Russian village as a whole. What is most significant here is that the newspaper brought these very disparate people together and gave them a common interest. 


\section{The Expanding Social Network of the Vladimir Newspaper}

This section explores the expanding social networks that developed around the newspaper from 1853, when Konstantin Nikitich Tikhonravov became editor, to the emancipation of the serfs in 1861. Tikhonravov's own network expanded over time from one friend from his seminary days to include a large swath of those working on regional issues in Russia by the time of his death in 1879. He was one of the longest-serving editors in Russia and was widely acknowledged at the time as one of the best in Russia, for in the paper he created an unfolding historical and statistical narrative of the past and present of Vladimir Province. ${ }^{170}$ Born in 1822, Tikhonravov grew up in a precarious family situation. He became an orphan at three, when his father, a stenographer in a district court, died. His mother had died after giving birth to him. His stepmother took him to the Suzdal ecclesiastical school, where he did well, entering the Vladimir seminary in 1836.

At the seminary, the quiet, somewhat anxious Tikhonravov was befriended by the graduating Iakov Egorovich Protopopov (1815-1861), who guided him into the Vladimir bureaucracy and, later, the editorship. Protopopov was editor of the unofficial section of the paper from 1840 to 1843, during which time he focused on the study of history and archeology. He was a witty, sometimes caustic man from a solid clerical family, who had obtained a job at the governor's office-a prestigious spot, as it facilitated promotion - after he organized the library of the Vladimir governor, I. E. Kurut. He later brought Tikhonravov to work for the governor. Thus, for Tikhonravov, Protopopov was the crucial first contact in his social network.

In 1843, as part of his work in the governor's office, Tikhonravov was put in charge of the Vladimir Statistical Committee, where he worked for thirty-five years; during the first years, however, he was a one-man committee with little support from the bureaucracy or from outside. ${ }^{171} \mathrm{He}$ collected and systematized statistical information from the rural police. Until the empire-wide reorganization of statistical committees in 1851, Tikhonravov mainly compiled information for the governor's report without much input or assistance from anyone, but after 1851 it became a significant force for the study of the province. In the early years, Tikhonravov organized the material needed for the annual governor's report to the tsar and also compiled statistical tables on the condition of towns in the province for the Statistical Division of the Ministry of Interior Affairs. The most important connection he made during this time was with the governor, P. M. Donaurov, in whose office he worked. At the governor's request, he went on trips to gather statistical information, including on the condition of horse farms in Vladimir Province; in 1844, he published his first article 
in the Vladimir Provincial Newspaper on this topic. ${ }^{172}$ In this way, the governor and local officials came to know Tikhonravov. Without these official connections, he could not have reached out to society.

To become the editor of the unofficial section and do a satisfactory job, it was necessary to be part of several social networks. This was laid out in an 1847 letter from Protopopov to Tikhonravov giving advice on how to become editor. Protopopov asked Tikhonravov to "write me quickly and at length about your activities at the [governor's] office, of your relations with the head of the office, of the quantity and quality of your archaeological and other materials, of what the decent people [poriadochnye liudi], or, if you please, the Vladimir public [publika vladimirskaia] thinks of your articles, and which correspondents you have in mind for the province, aside from Borisov, with whom you should get acquainted with immediately." ${ }^{173}$ The social connection needed to serve as editor ranged from the bureaucracy to the town public and to the province-wide network of correspondents. It was not sufficient to merely have bureaucratic ties. Reflecting the social function of the unofficial section, the editor needed to have a good standing in society and a network outside the bureaucracy.

Tikhonravov followed Protopopov's advice, tapping into a network of factory owners and merchants based in the industrial centers of Ivanovo and Shuia. In 1850, Tikhonravov was named clerk of the statistical committee without extra pay; by 1854 he was named assistant clerk at 200 rubles a year. In 1856 he was made the head clerk of the committee at 800 rubles a year; only in 1861 was he named secretary of the statistical committee and relieved of his other duties as senior assistant in the governor's office. ${ }^{174}$ By the early 1850s, Tikhonravov had already created new ties to merchants and factory owners through this committee.

Tikhonravov used these connections to help him become editor. On April 28, 1853, Vladimir Governor V. I. Annenkov wrote that Vice-governor Murav'ev, who had worked closely with Tikhonravov on the statistical committee, "had personally informed me of his [Murav'ev's] lack of satisfaction with the condition of the provincial newspaper under its present editorship" and that since the editors of the official and unofficial sections could be different, he ordered that Tikhonravov be named the unofficial section's editor in order to make it "more varied, which is necessary to increase the number of subscribers, and through this the income of the provincial press itself." 175 Indeed, the number of subscribers had dropped from 310 when Dobrokhotov became editor in 1849 to just 248 in $1852 .{ }^{176}$ At the same time, the governor noted that Tikhonravov had been a member of the Russian Geographical Society and the Russian Archaeological Society since 1849 and "has occupied himself with the statistics and archaeology of Vladimir Province." ${ }^{177}$ It was not enough to simply say 
that the paper needed to bring in more money; the argument also included reference to Tikhonravov's scholarly standing, making him at least equivalent to Dobrokhotov in scholarly connections and writing. The merchants, who the governor hoped would bring in more subscription money, did begin to play a significant role in writing for the paper, as they had in the statistical committee.

After Tikhonravov became editor in 1853, the Vladimir Statistical Committee served as the editorial office of the Vladimir Provincial Newspaper. The minutes for the June 5, 1854, meeting of the committee stated that the "Vladimir Provincial Newspaper ... is the means to become acquainted with the province in all its aspects and should serve as the organ of the provincial statistical committee itself, as the Journal of the Ministry of Interior Affairs serves as the organ for the [statistical] committee of this ministry." 178 In 1855, the governor asked that 1000 rubles be reassigned from the press to the statistical committee for the publication of the Vedomosti. In addition, he ordered that all the back issues of the Vladimir paper be moved from the press to the statistical committee, as the latter was actually publishing the paper. ${ }^{179}$ The minutes of other meetings of the statistical committee in the 1850s show the committee making decisions as to which periodical the various works of the statistical committee's members should be submitted. The Vedomosti began to serve as a safe outlet for the works of committee members. The actions of the Vladimir Statistical Committee helped to organize social activity and to expand the reach of the Vladimir Provincial Newspaper.

Under Tikhonravov, the Vladimir Statistical Committee and the Vladimir Provincial Newspaper had parallel aims: to discover the province. Tikhonravov's articles show his belief that the systematic study of the local was the true aim of the newspaper. The 1845 statute for the unofficial section supported his position. In 1847 he wrote that the Vedomosti was established because the provinces "are members of the living body of Russia and must participate in her mental life. . . . The main goal [of the Vedomosti] is to discover and recognize the strengths of the province, delineate its special character and its meaning for the general life of Russia. . . . All provinces, while they resemble each other administratively, have their specificities, which manifest themselves particularly clearly in the morals and traditions of the people and in their means of trade and industry." 180 Tikhonravov strongly emphasized the primacy of the local over all other subjects. In his first editorial in 1853, he wrote, "I have a duty to tell the subscribers that the Vladimir Provincial Newspaper consists mainly of information on the province, and in agreement with the goals established for this newspaper it may be called and truly be a Vladimir newspaper.” At the end of 1853, Tikhonravov wrote that seventy articles on Vladimir province had already 
been published while he was editor and noted that he was "not able to talk about the internal good qualities of the articles, but one can say that so far nothing unrelated to the province has been printed in the unofficial part-not a line."181

Tikhonravov emphasized the centrality of science in the study of the local and outlined a complete program for such study. The first section, "Material for Statistics," included "all kinds of descriptions dealing with the contemporary condition of the province as a whole.” The second division, "Material for History and Archeology," would include "old acts, church records, descriptions of churches and monasteries, the description of monuments of antiquity and old ecclesiastical and civil architecture preserved in the province." In addition, the newspaper was to include news from the province and from the town, along with reprints dealing with discoveries in the arts and sciences. Significantly, in a later editorial, Tikhonravov described the last section as comprising "contemporary notes about important manifestations of public life [obshchestvennaia zhizn'] in Vladimir and in different towns of the province.”182 His program appealed both to amateur historians such as Borisov and members of the statistical committee interested in contemporary economic conditions.

The provincial statistical committees were a forerunner of the zemstvo, which was the center of self-governance and an active provincial civil society in the postreform period. In 1851, provincial statistical committees throughout the empire were reinvigorated as part of a reorganization of the land duties [zemskie povinnosti] peasants had to provide to the state and their owners. Such duties were "collected from local property for the purpose of maintaining local (i.e. provincial and subprovincial) institutions and services; e.g., the maintenance of local roads, the post, public buildings, local police and courts." 183 The dues consisted of both cash and labor services. In order to organize these often arbitrarily levied duties along what was hoped to be more rational lines, committees on duties were established in 1851 . Like the zemstvo, these committees were composed of representatives of different estates and carried out various public services such as public health programs. In fact, the zemstvo was introduced in 1864 along with a new regulation on duties. ${ }^{184}$ Many committees on duties failed to attract enough representatives from different estates because they were not given sufficient power to fulfill their responsibilities; this influenced the later decision to give substantial authority to the zemstvo. In areas without the zemstvo, committees on duties carried out many of their educational and medical functions.

The Central Statistical Committee was deeply involved in the establishment of the zemstvo. The Zemskii otdel, the governmental body responsible for drafting the final administrative reforms in 1864, including the introduction of the zemstvo, 
emerged out of this committee, to which the provincial statistical committees were subordinated. ${ }^{185}$ "The Zemskii otdel," wrote Daniel Orlovsky, "under the direction of Ia. A. Solov'ev, who had served his apprenticeship under Kiselev in the Ministry of State Domains, became the focal point for the MVD's work on the emancipation."186 We can also see the links between the statistical committees and the zemstvo in the fact that Tikhonravov worked in St. Petersburg during 1859 in the Commission of Provincial and District Institutions, which helped to prepare the reforms of local government and the zemstvo. ${ }^{187}$

The main focus of the Vladimir Statistical Committee's work was on industry. This was reflected in the voluntary enrollment of Shuia and Ivanovo factory owners as members of the committee. In 1855, the statistical committee received 219 rubles in donations from sixteen individuals. Two of the donors were nobles, twelve were merchants (including five associated with the Old Belief), and two were of an unidentified estate. Thus, in the first collection of money to support the committee, only 12 percent of the donors were nobles, while 75 percent were merchants. Merchants associated with the Old Belief (either having converted to edinoverie, an officially sanctioned halfway house for Old Believers, in the 1830s or having been investigated by the MVD for being suspected as Old Believers) made up 31 percent of the total and nearly half of the merchants listed. ${ }^{188}$ Some of these cultural Old Believers wrote many statistical descriptions of their own factories and the surrounding area in the pages of the Vladimir newspaper. Tikhonravov was the central organizing figure, so the statistically inclined factory owners were in regular contact with him.

Despite Tikhonravov's connections with society, he temporarily lost his job as editor in 1855. Some people still saw the Vedomosti as a bureaucratic tool rather than as the organizer of society it had become. In 1855, one A. S. Iordanskii was hired to replace Dobrokhotov as editor of the official section. It seemed that few people wanted the job, as two inside candidates had already rotated through the position without notable success. ${ }^{189}$ Unlike Tikonravov, Iordanskii had no prior writing or scholarly experience; instead, he had worked in the Moscow Department of the Senate, then in the Moscow District Court. As he informed Governor Annenkov in an 1855 letter applying for Dobrokhotov's position, he needed a job in Vladimir to be near his ill mother. ${ }^{190}$ Iordanskii also replaced Tikhonravov as editor of the unofficial section. Important people in the bureaucracy, including Governor Annenkov, who asked the provincial board to appoint Iordanskii, still did not see the unofficial section as really separate. Although the archival documents do not explain the reasons for Iordanskii's appointment, it is possible that Tikhonravov fell from favor with the governor during this unsettled time; many governors were replaced after Alexander II came to the 
throne, and Annenkov himself was forced to leave in 1856. It was often the case that a new governor would bring in his own people. As for Iordanskii, it soon became clear that he had no special skill as a writer. During his tenure in the unofficial sectionbetween August 1856 and January 1857—the paper consisted of reprinted articles from central papers and helpful hints such as "How to remove stains." 191

By January 1857, Tikhonravov once again was editor of the unofficial section, most likely assisted by his social network and the arrival of a new governor, E. S. Tilicheev, with whom he had a good rapport. In 1857, in his first editorial as the reappointed editor, Tikhonravov wrote that the paper would follow his 1853 program: "And so we will once again speak here specifically about Vladimir Province, about the contemporary and former life of this region; we hope that our colleagues, who have recently fallen silent, will once again with full sympathy respond to our call for participation in the provincial paper. ${ }^{\prime 92}$ Over the entirety of Tikhonravov's editorship, he drew in more than thirty permanent local correspondents, far more than had been the case in the past. ${ }^{193}$

Indeed, the Vedomosti was the site of a lively debate over the newly emerging figure of the capitalist that led to a further expansion of the paper's social networks. Central to the debate was the morality of factory life and of factory owners. Nobles charged that industry led to immorality, in contrast with the morality of traditional peasant villages; factory owners argued that their work was necessary for the nation and therefore moral. Others attempted to define a "moral capitalist" and to change the conditions of work.

The capitalists themselves were vocal in defending their activities. One of the common themes of factory owners' articles was that the rise of domestic industry strengthened the Russian nation. This is visible in an 1853 article by Ia. P. Garelin and I. A. Baburin, factory owners who were members of the Vladimir Statistical Committee. ${ }^{194}$ Both were investigated by the MVD during the 1850 s on suspicion of being Old Believers. In Garelin's case, his father had converted to Orthodoxy in 1831. The Garelins were among the founders of the textile industry in Ivanovo in the eighteenth century. In their article, Garelin and Baburin extolled the technological advancements of cotton manufacturers. They described how "before, about ten years ago, when Russian spinning of thread couldn't keep up with the demands of the factory owners, [cotton manufacturers] ordered thread from England through Moscow and St. Petersburg agents (mostly foreigners). At present, thanks to improved distribution and a modernized structure for Russian cotton spinning, Ivanovo factory owners go right to cotton spinners and buy thread of the necessary amount for their manufactory.” 195 
Garelin and Baburin argued that technological advancements were necessary for the continued existence of the cotton industry and for Russian industrial independence.

For these factory owners, the Vedomosti and the statistical committee offered a voice to justify and even celebrate their own achievements. In response to arguments that capitalists exploited workers, they argued that weaving was good for the peasants. Weaving "is one of the beneficial occupations of free hands," Garelin and Baburin stated. The peasants "during their time free from field work, weave calico at home or in manufactories. ... [Weaving] for a long time was the source of the well-being of the peasants, who, not having to move far from their families in order to find work and being occupied during the winter, have under their control a business with overly rewarded work." 196

Articles by nobles, however, criticized factory owners and presented an idealistic vision of Russia as a network of peasant farmers living traditional lives and still under the control of nobles, yet utilizing selected technological advances. Ia. A. Solov'ev, a nobleman and an enlightened bureaucrat who was in charge of the government body that created the zemstvo in 1864, was head of the land survey commission in Vladimir from 1853 to 1856, a position that gave him wide experience with peasants and bureaucrats. ${ }^{197}$ In an 1854 article, he argued that peasants were better off the further they were from capitalists' control. In this article, one of the first in Vladimir to use the word “capitalist” (kapitalist), Solov' ev ranked the different regions of the province according to the well-being of the people, not the profits of capitalists. He argued that such a differentiated view was necessary in order to have a fairer distribution of taxes and a more effective regulation of state peasants. "It seems to me," he wrote, "that for the people, craft is the more profitable, the less it depends from owner-capitalists [khoziaev-kapitalistov]." ${ }^{198}$ He ranked the regions so that Viazniki District, which was home to the ofeni or peddlers, and Vladimir District, with its tradition of master craftsmen, were the two areas most beneficial to the people and which displayed the least dependence of workers on capitalists. The least beneficial to the people was the Shuia region, where the cotton industry and factory labor dominated and workers were most dependent on capitalists.

The experience of the Vladimir Statistical Committee laid the foundation for the industrial auxiliary of the Iur'ev Agricultural Society (IAS). Enterprising landlords founded the society in 1854 in the district town of Iur'ev, Vladimir Province. Its original aim was to improve "agriculture, industry, and the peasant way of life [byt]." ${ }^{199}$ The Iur'ev society popularized the need to switch from the three-field system to crop rotation and fodder grass cultivation. In the first years of its founding, it seemed like a relatively traditional organization, dominated by practical landlords. 
Between 1854 and 1858, its journal ran many articles on the need to train peasants as overseers and administrators to shape the peasantry and the nobility into a more harmonious whole. As part of this early conservative attitude, members of the Iur' ev society did not support mechanization in industry, and they were not always in favor of its introduction in agriculture.

Beginning in 1859, the IAS began to benefit from the earlier experience of the Vladimir Statistical Committee and the Vedomosti. In that year, many industrialists from Ivanovo and Shuia joined the society. While earlier volumes of the society criticized the immorality of factory life, by 1860 the IAS journal included a large pro-industry section. The Vladimir Provincial Newspaper heralded its publication by noting that it was "the happy thought of V. V. Kalachev to add a manufacturing section, so needed in this province, second only to the capitals in industry." 200 This section included items more typical of the Vladimir Provincial Newspaper, such as a statistical essay on Vladimir Province, news on the opening of factories, and biographies of model capitalists. As an example of the latter, a biography of Ivan Baranov, an Aleksandrov factory owner, described him as "an experienced person, an active and true patriot, [the] first to have the happy idea that in a state as large as our fatherland ... there must be dyeing agents, which could completely substitute for foreign madder." 201 This approach was entirely in line with the works of the factory owners themselves, who emphasized the importance of native industry for the strength of the country. Other parts of the volume gave technical and business news directed at owners of textile factories. Without the prior experience of the Vedomosti and the statistical committee, it is unlikely that the IAS could have published so much in a short period of time. Again, the Vedomosti created a print community that brought together groups of people who otherwise would have likely not met and gave them a shared reference point.

After 1855, Tikhonravov became involved with the preparations for the emancipation of the serfs. In 1859, he went to St. Petersburg to work for the Zemskii otdel of the statistical committee of the MVD. On the Commission of Provincial and District Institutions, he became known as an expert on local issues. This was reflected in a letter dated August 17, 1861, in which Vladimir Governor Tilicheev asked Tikhonravov to "write about when you think you will return, if D. P. [Gavrilov] will soon return . . . and about anything else interesting that you know. For we provincials [provintsialy] are terribly thirsty for news in general." ${ }^{202}$ This shows the connection between Tikhonravov and Gavrilov, who was a member of the IAS and also the leader of the liberal first minority in the Vladimir provincial gentry committee for peasant affairs. ${ }^{203}$ 
The IAS played a crucial role in preparing its members to take pro-emancipation stances in the Vladimir provincial gentry committee, which had a conservative majority and two liberal minorities. In 1857, the society gained the protection of Grand Princess Elena Pavlovna, a leading voice for emancipation. ${ }^{204}$ In the IAS, there was a conflict between the older generation, whose interest was more in market agriculture and profits, and the younger generation, which came of age in the 1840s, the era of Romanticism and valorization of the Russian peasant. ${ }^{205}$ Three of the six members of the first minority were members of IAS, ${ }^{206}$ and three were born in the 1820 s, making them younger than members of the conservative majority, led by S. N. Bodganov (1791-1868), marshal of the nobility for Vladimir Province. ${ }^{207}$ Although eight members of the IAS were part of the conservative majority, aside from A. N. Dubenskii (1821-after 1859), who later joined the first minority, those whose birth dates can be found were born in the $1810 \mathrm{~s} .{ }^{209}$ I. S. Bezobrazov, the leader of the second minority, which was more liberal than the majority but less so than the first minority, was also a member of the IAS. ${ }^{209}$

During the preparation for the Great Reforms, the Vladimir Provincial Newspaper reported on the publications and announced the meetings of the IAS, often in the same article as the publications of the statistical committee. For example, a note from 1860 stated that both the IAS and the statistical committee were "increasing the circle of their activity" by publishing their journals. ${ }^{210}$ Tikhonravov was cautious by nature, so he did not comment on the actions of the Vladimir gentry committee's minorities, but by featuring the work of the IAS, he helped to spread its ideas.

In the years after 1861, Tikhonravov continued to organize the correspondents of the newspaper, but the era of the Great Reforms was a high point that was not repeated. Much of his publishing energy went into editing the works of the Vladimir Statistical Committee, which began to be published in 1863. The committee's journal often served as a permanent bound record of important articles that had earlier been published in the Vedomosti. He brought in new correspondents, such as I. A. Golyshev, a publisher of lubki or folk prints whom Tikhonravov introduced to archaeology and history. Unfortunately, after Tikhonravov's death in 1879-he caught cold while traveling to Moscow to see some of his archeological finds displayed in the Anthropological Exhibition-many correspondents drifted away from the Vedomosti and began to publish in other venues.

The history of the Vladimir Provincial Newspaper is closely bound up with the history of K. N. Tikhonravov. This section has traced how the newspaper and Tikhonravov expanded social networks from the governor's office to include factory owners, nobles, St. Petersburg bureaucrats, and scholars throughout the empire. After 1855, Tikhonravov was able to take part in the preparations for the Great Reforms 
and connect with a national audience. The Vladimir newspaper was the nexus of his social network, and while he traveled far, he always came back to it. And Vladimir was not the only local newspaper. Multiply this network many times and one begins to see the role the newspapers could potentially play in organizing social life and bringing together unlikely interlocutors. Did this actually happen on a broad scale? The following section argues that it did and focuses on a particularly vibrant period of the vedomosti's history - the era of the Great Reforms.

\section{A Haven for Liberal Thought: The Vedomosti and the Era of Great Reforms}

By the late 1850s, many provincial newspapers had experienced a major upswing in their coverage of current affairs as part of the era of the Great Reforms. As a result, many articles were published outside the strict interpretation of the official program. In 1858, the censorship authorities allowed articles on the peasant question, but not on the peasants' right to land. The newspapers were forbidden to print anything challenging local authorities or any polemical articles. Only in 1863 were the vedomosti given the right "to reprint political news from all existing Russian official publications" as well as to publish "editorials on foreign politics and domestic policies." ${ }^{211}$ A recent content analysis of the Tobol'sk Provincial Newspaper during the era of Great Reforms shows a peak of liberal articles in 1858, with a lower but still stable number of liberal pro-emancipation works in the early 1860s. ${ }^{212}$ This suggests that it took some time to reestablish censorship control after widening the program. Because it usually took between three and six months after publication for newspapers to reach the central censorship authorities, enforcement in practice depended on local censors and the patronage of governors or vice-governors who supported critical views, as was the case in several provinces. ${ }^{213}$

In Tver, the epicenter of the liberal movement and the only province where the liberals were in the majority in the provincial gentry committee, the newspaper was closely linked to the leader of the liberals, the marshal of the nobility, A. M. Unkovskii. ${ }^{214}$ Unkovskii wrote that the editor of the Tver Provincial Newspaper, D. S. Rzhevskii was "my close friend and the best man of that time in Tver." ${ }^{15}$ Before coming to Tver, Rzhevskii had been a censor in Moscow, where he was fired for allowing the publication of V. Likhachev's story “The Dreamer” in The Muscovite. A report from a Tver gendarme, Simanovskii, noted that "this rapprochement has for a long time consisted of the most friendly relations and no one in the town was unaware that Unkovskii spent most of his evenings at Rzhevskii's home.” Here, the gendarme added, "they read all that Unkovskii wrote for the committee and the discussion touched upon the peasant 
question almost exclusively." 216 However, because the newspaper was subordinated to the governor, not the marshal of the nobility, the Tver paper did not have the support that allowed other papers to publish broadly. The paper resorted to various ruses, such as reprinting an article on the banquet celebrating the opening session of the Tver provincial gentry committee, which included many speeches dealing with emancipation that otherwise would not have been allowed. ${ }^{217}$ It also reported on the sobriety movement and sobriety strikes, which many saw as a protest against serfdom.

The final straw for the authorities was Rzhevskii's article "January 12, 1860, in Tver," which dealt with a gathering of Moscow University graduates living in Tver on the anniversary of the university's founding. Rzhevskii noted that among the participants were those "whose noble frame of mind and useful activity have earned universal respect.” The police saw this as a veiled reference to Unkovskii, who had just been relieved of his post as marshal of the nobility. Although Rzhevskii protested that he meant the Tver vice-governor and the head of the Tver treasury, who also participated in the gathering, the authorities did not believe him and he lost his job as editor in March 1860. ${ }^{218}$

The Tver Provincial Newspaper is a case where the newspaper provided a veiled forum for liberal ideas and served as a part of a larger face-to-face social network. However, the ideas it could express in print were more limited than in provinces with liberal governors or vice-governors who protected the newspapers, as was the case in Samara. The Samara Provincial Newspaper wrote during this time about the lack of educational opportunities, including for women. It even published a six-part series on the problems of bureaucratic life, which argued that bribery was a structural problem stemming from low salaries and the general arbitrariness of the system and that only the consistent rewarding of honest work could change the situation. The censor was fired and a new censor was named who was connected to the N. G. Chernyshevskii circle and to the Land and Liberty movement. ${ }^{219}$ This did not have the desired effect from the government's point of view.

In Riazan, the vice-governor and satirist M. E. Saltykov-Shchedrin acted as a protector for the provincial newspaper. He organized the publication of articles on all aspects of the Riazan region and even pressured his bureaucrats to write for the paper to such a degree that they complained that if they were not able to do so, their advancement was hindered. ${ }^{220}$ Saltykov himself was the editor of the newspaper in 1858, when he published much on the peasant question. This was noted with alarm by the Riazan marshal of the nobility, A. V. Selivanov, in a September 1858 letter to the Riazan governor. Selivanov stated that "the Riazan Provincial Newspaper has been printing several articles dealing with the contemporary question of peasant affairs; 
these articles ... touch upon even the discussion of the future rights of peasants on land. The Riazan Newspaper . . . is accepted among the people as an official echo of the government and, in the case of the discussion of the duty of the landlords to give land, the word 'ownership' is often used, and I am afraid that the half-literate peasants and priests will interpret this according to their own understanding and tell the people that which is not the intent of the government and which cannot be; and because of this ... I ask that the Provincial Newspaper not print [such] articles until the approval of the legislation on the reform so as to prevent unrest among landlord peasants." 221

As a result, Saltykov-Shchedrin ceased to be the editor, but he chose in his place F. T. Smirnov whom he knew through his liberal articles in the Moscow Newspaper. Smirnov's editorial in 1859 stated that the Riazan paper was to be a voice for "our local interests and needs." The articulation of these demands was of great importance because "the degree of understanding of [these interests and needs] determines the level of our personal self-awareness and our rights to participation in common public life. Without developing our self-awareness, without declaring one's existence by rational words and the acts that suit them, we will become only an obstacle in this life." ${ }^{222}$ Liberal views were common on the pages of the newspaper. A. I. Koshelev and F. S. Ofrosimov, leaders of the liberal minority of the Riazan provincial gentry committee, wrote frequently for the Riazan newspaper, helping to spread the ideas of the liberal nobility. As Smirnov wrote, "life without thought is everywhere becoming an anachronism. Society is waiting for a human word in our provincial life as well, is searching for signs of thought, is following every event and placing on the pages of journals and newspapers everything that is in any way notable. This attention is not the result of a desire to satisfy an empty curiosity, but serves the needs of our time.”223 Like many contemporaries of the Great Reforms, Smirnov was later disillusioned. In 1862, accused of atheism and of being a member of an antigovernment organization, he lost his job as editor. In his last editorial he wrote: "the posing of questions that might arouse polemics or the serious investigation of hopes and shortcomings ... all this is absolutely impossible for the editorship of the provincial newspapers. Independence from the program of local prejudices always calls forth a storm against any personal, independent opinion of the editor."224

Finally, the case of the Irkutsk Provincial Newspaper shows both the promise and limitations of liberalism. This newspaper had a wide distribution throughout Siberia and among Siberians in Moscow, St. Petersburg, and Kiev. ${ }^{225}$ The patronage of the governor-general of Eastern Siberia, Nikolai Murav'ev-Amurskii was necessary for the continued existence of such a critically inclined newspaper. Murav'ev himself was 
a remarkable character. At first acting on his own, and later with the blessing of St. Petersburg, he was able to colonize the left bank of the Amur River over the course of the 1850s and extract the Treaty of Aigun from China in 1858, which ceded the Amur region to Russia. For this he was later given the honorary suffix to his family name. He surrounded himself with many liberals and even radicals. The anarchist M. A. Bakunin, exiled in Irkutsk, wrote Herzen that Murav'ev-Amurskii "is entirely ours in convictions and in his deeds."226

Murav'ev-Amurskii also cultivated the Petrashevtsy, who had originally formed in St. Petersburg around M. V. Petrashevskii. They were interested in socialism and believed in "the rehabilitation of nature and sensuality, the free and harmonious development of the passions, and the vision of a renaissance of mankind founded on the liberation of human nature and the flowering of all its potentialities." ${ }^{227}$ Fyodor Dostoevsky took part in the group and, along with the future editor of the Irkutsk newspaper, N. A. Speshnev, was lined up to be shot on December 22, 1849, then pardoned at the last moment and sent to Siberia. Much of Dostoevsky's polemic against socialism as a new religion that put man in God's place was directed against the Petrashevtsy. ${ }^{228}$

In 1858, three leaders of this group were allowed to settle in Irkutsk: Petrashevskii; Speshnev, a radical revolutionary and the model for Nikolai Stavrogin in Dostoevsky's The Possessed; and F. N. L'vov. M. V. Zagoskin, who was later the editor of the Irkutsk Provincial Newspaper, described the three in his memoirs, illustrating the role of the social network in the vedomosti and the importance of the governor as protector: "In Irkutsk the three always lived together: Petrashevskii, N. A. Speshnev and F. N. L'vov. I became acquainted with them soon after the publication of the first number of the Irkutsk Provincial Newspaper, of which at first Speshnev was the editor. When I submitted my first article to Speshnev, they all received me well. Soon they moved near me on Bolshaia Street, and we met here often. Murav'ev was at that time carried away by liberalism and drew them to him. After a few of my articles in the Provincial Newspaper, Murav'ev wanted to meet me and we (I don't remember if it was with Speshnev or Petrashevskii) went to the governor-general's. Murav'ev's office had an entire corner crammed with foreign publications on Russia, and right then he invited all of us to use these books. Soon he set off for the Amur and took Speshnev with him as the head of his traveling office, and proposed that I take over the editorship of the Provincial Newspaper." 229

The Petrashevtsy thus were able to disseminate their worldview in print even while in Siberia. The Irkutsk Provincial Newspaper reflected their interest in critiquing contemporary society. The paper detailed the exploitation of workers in mines 
and forestry, which they openly discussed and criticized. ${ }^{230}$ An 1858 article on the wrongdoing of an elected subdistrict elder and the repression of the peasants who tried to vote him out became a huge scandal, which ended with the arrest of the elder. ${ }^{231}$ Other Siberian papers commented on the Irkutsk articles. In 1859, the Enisei Provincial Newspaper (Krasnoiarsk) published a criticism of the Irkutsk paper entitled "A Few Words on the False Understanding and Malicious Use of Openness [glasnost'].” Although the Enisei paper was generally much more moderate than the Irkutsk one, a few weeks after the attack, L. Mitropol'skii published an article in Enisei entitled "Openness," which said that "for good people, it is a reward, for bad ones it is a bridle, for the insulted — an appeal, for all of society — a true mirror.”232

The story of the peasant elder had ended well because Murav'ev supported the newspaper and its authors. This support was withdrawn after the even larger scandal of a duel in 1859 in which one of Murav'ev's favorites caused the death of another man. ${ }^{233}$ The newspaper reported on the duel, criticizing Murav’ev’s protégé and angering Murav'ev. Murav'ev then withdrew his protection from the newspaper and appointed a new editor, after which it became Murav'ev's mouthpiece. ${ }^{234}$ Strangely, however, between 1860 and 1862 the Petrashevtsy were allowed to publish an even more radical private newspaper entitled Amur, which criticized local officials, not sparing Murav'ev. ${ }^{235}$

\section{Conclusions}

In this paper, I have argued that the provincial newspapers provided a focal point for the creation of a provincial public. This public consisted of individuals of various estates who otherwise would have shared little. The public came of age in the late 1850 s and early 1860s, when the vedomosti in a whole range of provinces became lively, vital forums for debate of the most important questions of the day, including emancipation. The golden age of these newspapers was the era of Great Reforms. Afterward, the proliferation of private provincial periodicals, whose existence was partly due to the work of the vedomosti in creating an audience, gave authors and readers other outlets. In addition, many were drawn to work in the zemstvo. The vedomosti continued to exist until 1917, but they were no longer the sole outlet for provincial society. This diversity in itself suggests that the provincial public had reached a new level of maturity. In the pre-reform period, however, the provincial press was central in its creation of a self-aware public with ties to other provinces and to the empire as a whole. 


\section{Notes}

The epigraph is quoted from Alexander Herzen, Childhood, Youth, and Exile: Parts I and II of My Past and Thoughts, trans. J. D. Duff (Oxford, 1994), 269.

1. Ian F. McNeely, The Emancipation of Writing: German Civil Society in the Making, 1790s1820s (Berkeley, 2003), 9.

2. Douglas Smith, Working the Rough Stone: Freemasonry and Society in Eighteenth-Century Russia (DeKalb, Ill., 1999), 59. See Also: Marc Raeff, “Transfiguration and Modernization: The Paradoxes of Social Disciplining, Pedagogical Leadership, and the Enlightenment in EighteenthCentury Russia,” in his Political Ideas and Institutions in Imperial Russia (Boulder, Colo., 1994); Daniel R. Brower, The Russian City between Tradition and Modernity, 1850-1900 (Berkeley, 1990); Adele Lindenmeyr, Poverty Is Not a Vice: Charity, Society, and the State in Imperial Russia (Princeton, 1996); David Wartenweiler, Civil Society and Academic Debate in Russia, 1905-1914 (Oxford, 1999); Z. T. Golenkova, ed., Grazhdanskoe obshchestvo: Teoriia, istoriia, sovremennost' (Moscow, 1999).

3. Joseph Bradley, "Subjects into Citizens: Societies, Civil Society, and Autocracy in Tsarist Russia,” American Historical Review 107, 4 (October 2002): 1105.

4. See, for example: Terence Emmons and Wayne S. Vucinich, eds., The Zemstvo in Russia: An Experiment in Local Self-government (Cambridge, Eng., 1982); Thomas Porter, The Zemstvo and the Emergence of Civil Society in Late Imperial Russia, 1864-1917 (San Francisco, 1991); Mary Schaeffer Conroy, ed., Emerging Democracy in Late Imperial Russia: Case Studies on Local Self-government (the Zemstvos), State Duma Elections, the Tsarist Government, and the State Council before and during World War One (Niwot, Colo., 1998).

5. For a review of relevant European historical literature, see Celia Applegate, “A Europe of Regions: Reflections on the Historiography of Sub-National Places in Modern Times," American Historical Review 104, 4 (1999): 1157-1182. For Russia, see Richard Stites, Serfdom, Society, and the Arts in Imperial Russia: The Pleasure and the Power (New Haven, 2005); Catherine Evtuhov, "Voices from the Provinces: Living and Writing in Nizhnii Novgorod, 1870-1905," Journal of Popular Culture 31, 4 (Spring 1998): 33-48.

6. A. A. Sevast'ianova, Russkaia provintsial'naia istoriografiia vtoroi poloviny XVIII veka (Moscow, 1998), 67-100.

7. D. K. Yo [Daniel Clarke Waugh], Istoriia odnoi knigi: Viatka i 'ne-sovremennost'v russkoi kul'tury petrovskogo vremeni (St. Petersburg, 2003).

8. Gary Marker, Publishing, Printing, and the Origins of Intellectual Life in Russia, 1700-1800 (Princeton, 1985), 135-51.

9. As noted by M. P. Mokhnacheva, Zhurnalistika i istoricheskaia nauka, vol. 2, Zhurnalistika i istoriograficheskaia traditsiia v Rossii 30-70-kh gg. XIX v. (Moscow, 1999), 15. 
10. See, for example, G. F. Chudova, V te dalekie gody (Ocherki po istorii kraevedeniia Viatskoi gubernii) (Kirov, 1981); A. I. Ivanov, K. D. Ushinskii: Gimnazist, student, professor (Iaroslavl, 1973), 162-74.

11. N. N. Baladina, “A. I. Gertsen i 'Vladimirskie gubernskie vedomosti,”” in Uchenye zapiski Vladimirskogo gospedinstituta im. P. I. Lebedeva-Polianskogo (1958): 133-65.

12. See Mokhnacheva, Zhurnalistika.

13. An exception is V. V. Dement'eva, “Iz istorii vozniknoveniia 'Iaroslavskikh gubernskikh vedomostei,'” Sovetskie arkhivy, no. 6 (1981): 43-45.

14. For an intriguing use of this material to write a socioeconomic history of the raznochintsy and the newspapers in the Urals, see G. N. Vul'fson, Raznochinno-demokraticheskoe dvizhenie v povolzh'e i na Urale v gody pervoi revoliutsionnoi situatsii (Kazan, 1974), 79-137.

15. Cynthia Hyla Whittaker, Russian Monarchy: Eighteenth-Century Rulers and Writers in Political Dialogue (DeKalb, Ill., 2003), 46.

16. See Susan Smith-Peter, “How to Write a Region: Local and Regional Historiography,” Kritika: Explorations in Russian and Eurasian History 5, 3 (Summer 2004): 529, 530.

17. For administrative reform, see W. Bruce Lincoln, Nicholas I: Emperor and Autocrat of All the Russias (DeKalb, Ill., 1989), 180-195. For the cholera, see Roderick McGrew, Russia and the Cholera, 1823-1832 (Madison, Wis., 1965).

18. Smith-Peter, “How to Write a Region,” 530.

19. Susan Smith-Peter, "Defining the Russian People: Konstantin Arsen'ev and Russian Statistics before 1861,” History of Science 45, 1 (March 2007): 47-64.

20. Silvana Patriarcha, Numbers and Nationhood: Writing Statistics in Nineteenth-Century Italy (Cambridge, Eng., 1996), 17.

21. L. P. Burmistrova, Provintsial'naia gazeta v epokhu russkikh prosvetitelei (Gubernskie vedomosti Povolzh'ia i Urala 1840-50 gg.) (Kazan, 1985), 94.

22. Ibid., 4.

23. Marker, Publishing, Printing, 143.

24. V. Semennikov, “Literaturnaia i knigopechatnaia deiatel'nost' v provintsii v kontse XVIII i v nachale XIX vekov,” Russkii bibliofil, no. 8 (1911): 19. Italics in original.

25. Ibid., 20.

26. Ia. Grot, Zhizn' Derzhavina po ego sochineniiam i pis'mam i po istoricheskim dokumentam (St. Petersburg, 1871), 6: 581. 
27. Ibid., 600-01.

28. Semennikov, “Literaturnaia,” 21.

29. V. Semennikov, “Bibliograficheskii spisok knig, napechatannykh v provintsii so vremeni vozniknoveniia grazhdanskikh tipografii po 1807 god,” Russkii bibliofil, no. 3 (1912): 67.

30. Grot, Zhizn’, 581.

31. G. V. Antiukhin, Pechatnoe slovo Rossii: Istoriia zhurnalistiki Chernozemnogo tsentra strany XIX veka (Voronezh, 1993), 10.

32. N. P. Zagoskin, Istoriia Imperatorskogo Kazanskogo Universiteta za pervyia sto let ego sushchestvovaniia, 1804-1904 (Kazan, 1902), vol. 2, pt. 2 (1814-1819): 284.

33. Ibid., 290.

34. Ibid., 288.

35. Rossiiskii gosudarstvennyi istoricheskii arkhiv (RGIA), f. 560, op. 14, d. 36, l. 1. In My Past and Thoughts, Herzen incorrectly attributed the origins of the vedomosti to Minister of Internal Affairs D. N. Bludov. In itself this is not surprising; he had no access to archives while writing his memoir. However, many Soviet scholars repeated his attribution. Although Bludov implemented the vedomosti, he was not the originator of the idea.

36. G. M. Deich, “Gubernskie vedomosti kak istoricheskii istochnik,” in Vspomogatel'nye istoricheskie distsipliny (Leningrad, 1978), 9: 237.

37. Walter Pintner, “Government and Industry during the Ministry of Count Kankrin, 1823-1844,” Slavic Review 2, 1 (March 1964): 55.

38. "Egor Frantsevich Kankrin," in Otechestvennaia istoriia: Istoriia Rossii s drevneishikh vremen do 1917 goda, ed. V. L. Ianin et al. (Moscow, 1996), 2: 480.

39. RGIA, f. 560, op. 14, d. 36, 1. 1.

40. Marker, Publishing, 138.

41. Deich, “Gubernskie,” 237.

42. Ibid., 237.

43. Dement’eva, “Iz istorii,” 43.

44. Deich, “Gubernskie,” 237.

45. Polnoe sobranie zakonov Rossiiskoi Imperii (PSZ), sobranie 2-oe, No. 4036, Article 13. 
46. Ibid., Article 14.

47. For the theater, see Therese M. Malhame, "Yaroslavl Theater," in Modern Encyclopedia of Russian and Soviet History, ed. George N. Rhyne (Gulf Breeze, Fl., 1993), 55, supplement: 129-30. For the first private printing press, see V. Semennikov, "Literaturnaia i knigopechatnaia deiatel'nost' v provintsii v kontse XVIII i v nachale XIX vekov,” Russkii bibliofil, no. 6 (1911): 33. For the agricultural society, see B. V. Tikhonov, "Obzor 'zapisok' mestnykh sel'skokhoziaistvennykh obshchestv 30-50-kh godov XIX v.,” in Problemy istochnikovedeniia (Moscow 1961), 9: 152-56.

48. Dement'eva, “Iz istorii,” 44.

49. Ibid., 45.

50. RGIA, f. 560, op. 14, d. 36, 1. 90, 89ob, 89, 90-90ob.

51. Gosudarstvennyi Arkhiv Vladimirskoi Oblasti (GAVO), f. 40, o. 1, d. 889, 1. 126ob-127.

52. Dement'eva, “Iz istorii,” 45.

53. Deich, “Gubernskie,” 238. By 1857, newspapers began to be published in Siberia and Central Asia. Ibid., 238-39.

54. PSZ, sobranie 2-oe, No. 10304, Articles 88, 95.

55. Mokhnacheva, Zhurnalistika, 33.

56. PSZ, sobranie 2-oe, No. 10304, Article 91.

57. Antiukhin, Pechatnoe, 48.

58. Rossiiskaia gosudarstvennaia biblioteka, Otdel rukopisei, f. 178, op. 1, t. 8, ch. 1, n. 11,161, d. 1,10 , and n. 11,166, d. 1.

59. PSZ, sobranie 2-oe, No. 10304, Article 89.

60. PSZ, sobranie 2-oe, No. 4036, Article 32. According to the statute, "every post office” and “every ministry and main administration” would receive a free copy. Ibid., Articles 46, 48.

61. RGIA, f. 560, op. 14, d. 36, 1. 97. The relevant passage is in PSZ, sobranie 2-oe, No. 4036, Article 31, which stated that "every treasury" was to give 300 rubles.

62. GAVO, f. 40, o. 1, d. 889, 1. 128 ob.

63. GAVO, f. 40, o. 1, d. 889, 1. 134. Smirnov's 1834 report stated that the 300 rubles from the board was divided up among the workers and meant that they each often received only 80 rubles a year. 
64. See A. Kirillov, Materialy dlia istorii Vladimirskoi Gubernskoi Tipografii (Vladimir, 1897).

65. GAVO, f. 40, op. 1, d. 9531, 1. 5ob-6.

66. GAVO, f. 40, op. 1, d. 9637, 1. 130-31.

67. GAVO, f. 40, op. 1, d. 9531, 1. 6ob.

68. Antiukhin, Pechatnoe, 51, 53. For an excellent discussion of the intent and results of such announcements for the official section of the newspaper, see N. N. Ulashchik, "Minskie gubernskie vedomosti kak istoricheskii istochnik," in Problemy istochnikovedeniia (Moscow, 1959), 7: 112-49.

69. Deich, “Gubernskie,” 242. The advertisement read: “The unmarried noblewoman Natal'ia Ivanovna Dmitrieva is selling her serf with his mother and sister, etc.”

70. Antiukhin, Pechatnoe, 52.

71. GAVO, f. 40, op. 1, d. 9531, 1. 806.

72. GAVO, f. 40, op. 1, d. 9531, 1. 12.

73. GAVO, f. 40, op. 1, d. 9636, l. 2ob. In Vladimir, people could subscribe to the unofficial section separately from the start. This does not seem to have been the case everywhere, as separate unofficial section subscriptions were introduced in Voronezh only in 1847. See Antiukhin, Pechatnoe, 58.

74. These numbers are taken from GAVO, f. 40, op. 1, d. 9637. A. V. Smirnov, Ukazatel' soderzhaniia neofitsial'noi chasti Vladimirskikh gubernskikh vedomostei s 1838 po $1900 \mathrm{~g}$. (Vladimir, 1902), gives the number of private subscribers at 239. However, this analysis looks at both individual and institutional subscribers to get a full picture of the audience.

75. O. V. Moriakova, Sistema mestnogo upravleniia Rossii pri Nikolae I (Moscow, 1998), 71.

76. GAVO, f. 40, op. 1, d. 9637, 1. 130-31. This list does not differentiate between official and unofficial subscription money and is incomplete in that the Gorokhovets police chief and the Pereslavl mayor did not send in the amount of money collected. However, it does provide a rough sense of where most of the money was coming from.

77. William Blackwell, The Beginnings of Russian Industrialization, 1800-1860 (Princeton, 1968), 116.

78. G. S. Isaev, Rol' tekstil'noi promyshlennosti v genezise i razvitii kapitalizma v Rossii, 1760-1860 (Leningrad, 1970), 71, 216.

79. Mokhnacheva, Zhurnalistika, 67. 
80. Ibid.

81. Boris Gorshkov, "Democratizing Habermas: Peasant Public Sphere in Pre-Reform Russia," in Russian History/ Histoire Russe 31, 4 (Winter 2004): 379 notes that literate peasants read the vedomosti to other peasants.

82. Vladimirskie gubernskie vedomosti (VGV), 1839, n. 3. For identification of this unsigned article as Herzen’s, see B. F. Egorov and G. G. Elizavetina, eds., Letopis’zhizni i tvorchestva A. I. Gertzena, vol. 1 (Moscow, 1974), 190.

83. VGV, 1839, n. 44.

84. For works by priests, see, for example: VGV 1850, n. 52, 1851, n. 2, n. 15, n. 36.

85. VGV, 1852, n. 9.

86. VGV, 1852, n. 30 .

87. PSZ, sobranie 2-oe, No. 4036, Articles 15-27.

88. A. I. Stan’ko, Russkie gazety pervoi poloviny XIX v. (Rostov, 1969), 20.

89. A. F. Korostin, Nachalo litografii v Rossii (Moscow, 1943), 74.

90. G. A. Ozerova, "Istochniki kraevedcheskoi bibliografii (gubernskie vedomosti i ukazateli ikh soderzhaniia),” Trudy Gosudarstvennoi publichnoi biblioteki imeni M. E. Saltykova-Shchedrina, no. 3/6 (1957): 128.

91. Burmistrova, Provintsial'naia, 74.

92. Iu. S. Zobov, “Rol’ Orenburga v issledovanii vostoka v 30-50-kh godakh XIX veka,” in Rossiia i vostok: problemy vzaimodeistviia, ed. N. N. Alevras et al. (Cheliabinsk, 1995), 1: 105.

93. Mokhnacheva, Zhurnalistika, 34.

94. Ozerova, “Istochniki,” 128.

95. E. V. Letenkov, Gubernskie, oblastnye, voiskovye, eparkhial'nye vedomosti, 1838-1917 (St. Petersburg, 2005), 19-22, 101.

96. Mokhnacheva, Zhurnalistika, 46.

97. VGV, 1838, no. 50. Italics in original. Also see A. I. Gertsen, Sobranie sochinenii v tridtsati tomakh (Moscow, 1954), 1: 376.

98. Gertsen, Sobranie, 376.

99. Ibid., 374 . 
100. Baladina, “A. I. Gertsen,” 143.

101. Prodolzhenie svoda zakonov Rossiiskoi Imperii (St. Petersburg, 1852), 16: Addendum to Statute 648, Article 153.

102. Dement'eva, “Iz istorii,” 45.

103. M. V. Ptukha, Ocherki po istorii statistiki v SSSR (Moscow, 1959), 2: 298-329; W. Bruce Lincoln, In the Vanguard of Reform: Russia's Enlightened Bureaucrats, 1825-1861 (DeKalb, Ill., 1982), 109-25.

104. Nathaniel Knight, "Science, Empire, and Nationality: Ethnography in the Russian Geographical Society, 1845-1855,” in Imperial Russia: New Histories for the Empire, ed. Jane Burbank and David Ransel (Bloomington, Ind., 1998), 108-41.

105. See also Catherine B. Clay, "Russian Ethnographers in the Service of the Empire," Slavic Review 54, 1 (Spring 1995): 45-61.

106. Out of 2115 articles published in the Vladimir Provincial Newspaper between 1838 and 1868, only 49 were ethnographic in nature, although those 49 were generally well organized and often used Russian Geographical Society programs to collect material in a systematic way. See Mokhnacheva, Zhurnalistika, 64.

107. Burmistrova, Provintsial'naia, 55.

108. Mokhnacheva, Zhurnalistika, 56, 57.

109. Antiukhin, Pechatnoe, 68, 57.

110. Ibid., 57.

111. Burmistrova, Provintsial'naia, 43, 71, 100.

112. Deich, “Gubernskie,” 242.

113. A. V. Smirnov, Materialy dlia biografii K. N. Tikhonravov: Pis'ma k nemu raznykh lits (Vladimir, 1900), 17. For Kozhin, see N. V. Frolov, Predvoditeli dvorianstva Vladimirskoi gubernii (Vladimir, 1995), 58. P. V. Akul’shin, "Pavel Sergeevich Kozhin: Vladimirskii dvorianin i Riazanskii gubernator,” Materialy oblastnoi kraevedcheskoi konferentsii (22 aprelia 2005 g.) (Vladimir, 2005), 1: 27-30 states that Kozhin was terrifying when angry.

114. Burmistrova, Provintsial'naia, 70, 68.

115. Antiukhin, Pechatnoe, 74.

116. Ibid. 
117. Mokhnacheva, Zhurnalistika, 34.

118. Antiukhin, Pechatnoe, 75.

119. M. Lemke, Ocherki po istorii russkoi tsenzuryi zhurnalistiki XIX Stoletiia (St. Petersburg, 1904), 293.

120. This process is clearly visible in Tikhonravov's correspondence, which became increasingly varied and far-flung over time. See Smirnov, ed., Materialy dlia biografii. Borisov's letters, found on pages 18-117, show a similar gradual expansion of both local and national contacts.

121. N. P. Ogarev, Izbrannye sotsial'no-politicheskie i filosofskie proizvedeniia (Moscow, 1952), 101-05.

122. See Viktor Berdinskikh, Uezdnye istoriki: Russkaia provintsial'naia istoriografiia (Moscow, 2003), for discussion of the role of priests' sons in local studies throughout Russia.

123. Laurie Manchester, “Secular Ascetics: The Mentality of Orthodox Clergyman’s Sons in Late Imperial Russia” (Ph.D. diss., Columbia University, 1995), 264.

124. Gregory Freeze, The Parish Clergy in Nineteenth-Century Russia: Crisis, Reform, CounterReform (Princeton, 1983), 123.

125. Manchester, “Secular,” 263.

126. Berdinskikh, Uezdnye, passim.

127. A. V. Smirnov, Urozhentsy i deiateli Vladimirskoi gubernii (Vladimir, 1989), 3: 37-38.

128. E. Zhurbina, Iskusstvo fel'etona (Moscow, 1965), 200.

129. VGV, 1849, n. 26.

130. VGV, 1849, n. 50.

131. Smirnov, Urozhentsy, 29.

132. N. P. Barsukov, Zhizn’i trudy M. P. Pogodina (The Hague, 1969), 10: 417.

133. Smirnov, Urozhentsy, 35. Ironically, Soviet archeologists confirmed Dobrokhotov's reconstruction of the princely residence in Bogoliubovo, suggesting it was not as unscientific as Tikhonravov argued. See V. M. Maslov, “Arkheologicheskoe izuchenie Vladimira i Bogoliubova s 30-kh godov XIX veka do nastoiashchego vremeni,” in Pamiatniki istorii i kul'tury (Iaroslavl, 1983), 2: 17.

134. William Mills Todd III, Fiction and Society in the Age of Pushkin: Ideology, Institutions, and Narrative (Cambridge, Mass, 1986). 
135. VGV, 1849, n. 33.

136. VGV, 1852, n. 49.

137. VGV, 1849, n. 43. This is a play on words, as a talent originally was a type of money used in the classical world.

138. VGV, 1849, n. 33.

139. Ibid.

140. Ibid.

141. Dobrokhotov was interested in archaeology. See, for example, his article on kurgans he had excavated himself in VGV, 1852, n. 31, and an article in VGV, 1852, n. 10, where he praises A. S. Uvarov's book on his archaeological digs on the shore of the Black Sea.

142. Smirnov, Urozhentsy, 40.

143. VGV, 1844, n. 37.

144. See the discussion of the Rogozhsk and Preobrazhensk Cemeteries (or communities) in William L. Blackwell, The Beginnings of Russian Industrialization, 1800-1860 (Princeton, 1968), 212-29.

145. Smirnov, Urozhentsy, 41.

146. These materials are put to good use in Valerie Kivelson, Autocracy in the Provinces: The Muscovite Gentry and Political Culture in the Seventeenth Century (Stanford, 1996).

147. A. D. Stepanskii, Istoriia nauchnykh uchrezhdenii i organizatsii dorevoliutsionnoi Rossii (Moscow, 1987), 23.

148. Smirnov, Urozhentsy, 46.

149. VGV, 1847, n. 20.

150. V. Dal’, Tolkovyi slovar’zhivogo velikorusskogo iazyka (Moscow, 1955), 1: 547.

151. VGV, 1847, n. 20.

152. N. V. Frolov and E. V. Frolova, Kovrovskii krai pushkinskoi pory (Kovrov, 1999), 61. See also Susan Smith-Peter, "Books Behind the Altar: Religion, Village Libraries, and the Moscow Agricultural Society,” Russian History/Histoire Russe 31, 3 (Fall 2004): 213-33.

153. Gosudarstvennyi arkhiv Ivanovskoi oblasti (GAIO), f. 107, op. 1, d. 134, l. 3. The article was in VGV, 1838, no. 39. 
154. VGV, 1849, n. 49.

155. VGV, 1851, n. 12.

156. VGV, 1849, n. 40.

157. VGV, 1850, n. 23.

158. VGV, 1849, n. 40.

159. Mokhnacheva, Zhurnalistika, 70.

160. VGV, 1851, n. 12.

161. Mokhnacheva, Zhurnalistika, 71; Spisok chinam, sostoiashchim na sluzhbe po Vladimirskoi gubernii na 1854 god (Vladimir, 1854), 28-29.

162. VGV, 1851, n. 16.

163. VGV, 1852, n. 12.

164. VGV, 1849, n. 52.

165. VGV, 1850, n. 45. During this time rodina often meant the local area in which one lived or grew up and not the nation as a whole.

166. Ibid.

167. VGV, 1850, n. 46.

168. VGV, 1848, n. 42, n. 47.

169. “Vystavka sel'skikh i gorodskikh proizvedenii v g. Iur'ev-Pol’skom pri otkrytii Obshchestva Sel’skago Khoziaistva,” Zhurnal sel’skago khoziaistva, no. 12 (1854), otdel I: 260.

170. Mokhnacheva, Zhurnalistika, 70.

171. Smirnov, Urozhentsy, 158-60.

172. Ibid., 160-61.

173. Ibid., 21.

174. Ibid., 158-159, 220.

175. Ibid., 36-37.

176. Ibid., 31. 
177. Ibid., 36.

178. GAVO, f. 431, op. 1, d. 4, 1. 2. This argues against Mokhnacheva's devaluation of the role of the statistical committee. Although it is true that the vedomosti were active for many years before the reinvigoration of the statistical committees in 1851, once that happened, the committees did play a leading role in the vedomosti, as we clearly see in Vladimir. Cf. Mokhnacheva, Zhurnalistika, 18-19, 30.

179. GAVO, f. 431, op. 1, d. 6, 1. 9ob.

180. VGV, 1847, n. 9.

181. VGV, 1853, n. 19, n. 50. Tikhonravov’s italics.

182. VGV, 1853, n. 19, n. 50.

183. Terence Emmons, The Russian Landed Gentry and the Peasant Emancipation of 1861 (Cambridge, Eng., 1968), 81.

184. B. B. Veselovskii, Istoriia zemstva za sorok let (St. Petersburg, 1909), 1: 12.

185. S. Frederick Starr, Decentralization and Self-government in Russia, 1830-1870 (Princeton, N.J., 1972), 161-62.

186. Daniel T. Orlovsky, The Limits of Reform: The Ministry of Internal Affairs in Imperial Russia, 1802-1881 (Cambridge, Mass., 1981), 39.

187. Smirnov, Urozhentsy, 212. See also Starr, Decentralization, 161.

188. GAVO, f. 431, o. 1, d. 8, 1. 27. This was unusual for provincial statistical committees, according to Berdinskikh, who argues that the composition of the Viatka Statistical Committee was typical for committees nationally in that roughly one-half of its members were parish priests. See V. A. Berdinskikh, Russkaia provintsial'naia istoriografiia vtoroi poloviny XIX veka (Moscow, 1995), 61.

189. GAVO, f. 40, op. 1, d. 15080, l. 15-16.

190. GAVO, f. 40, op. 1, d. 15080, 1. 2-2a.

191. Smirnov, Urozhentsy, 198.

192. Ibid., 200.

193. Mokhnacheva, Zhurnalistika, 66.

194. I. A. Baburin, who was for a short time the mayor of Voznesenskii Posad after its establishment as a posad (town with self-government) in 1853, donated twenty-five rubles in 
1856. Garelin was also mayor for a short time in 1853 and wrote one of the first articles received by the statistical committee, “An Ethnographic Description of Shuia Region and its Surrounding Area,” in 1855. For more on Garelin, see the informative work of K. E. Baldin, Iakov Garelin: Predprinimatel', istorik, metsenat (Moscow, 1993).

195. VGV, 1853, n. 49.

196. VGV, 1853, n. 51.

197. “Ia. A. Solov’ev,” Russkii biograficheskii slovar' (St. Petersburg, 1909), 19: 93; Ia. A. Solov’ev, “Zapiski Senatora Ia. A. Solov’ev,’ Russkaia starina 34 (1882): 111.

198. VGV, 1854, n. 29.

299. N. Dubenskii, “Otkrytie Vysochaishe utverzhdennogo Iur'evskogo obshchestva sel'skogo khoziaista i deistviia ego v perviia sobraniia,” Zhurnal sel'skogo khoziaistva, no. 11 (1854), otdel I: 117.

200. VGV, 1860, no. 16.

201. Madder is a plant that produces a red dye. K. Tikhonravov, "Biograficheskie ocherki izvestneishikh manufakturistov i zavodchikov Vladimirskoi gubernii,” Zapiski Iur'evskogo obshchestva sel'skogo khoiziaistva (1860): 29.

202. Smirnov, Urozhentsy, 212-13.

203. L. P. Gorlanov, "Podgotovka krest’ianskoi reformy 1861 g. vo Vladimirskoi gubernii,” in Voprosy sotsial'no-ekonomicheskoi istorii Vladimirskogo kraia perioda feodalizma (Vladimir, 1979), 74. Gorlanov terms Gavrilov's group the second minority, but I will follow Kornilov and Emmons' use of the term first minority. See A. A. Kornilov, “Gubernskie komitety po krest'ianskomu delu v 1858-1859 gg.” Russkoe bogatstvo, no. 5 (1904): 68; Emmons, Russian, 158-60.

204. “Cherezvychainoe sobranie Iur'evskogo obshchestva sel'skogo khoziaistva 24-go sentiabria 1857 goda,” Zhurnal sel’kogo khoziaistva, no. 2 (1859), supplement: 9. On Elena Pavlovna’s plan for emancipating her own serfs, see W. Bruce Lincoln, “The Karlovka Reform,” Slavic Review 28, 3 (September 1969): 463-71.

205. See my review of S. A. Kozlov, Agrarnye traditsii i novatsii v doreformennoi Rossii (tsentral'no-nechernozemnye gubernii) (Moscow, 2002) in Kritika 4, 4 (Fall 2003): 985-90.

206. Kornilov, “Gubernskie,” 58, Emmons, Russian, 158; “Spisok gg. chlenov i korrespondentov Iur'evskogo obshchestva sel’skogo khoziaistva,” Zhurnal sel'skogo khoziaistva, no. 2 (1859), supplement: 23-28.

207. Gorlanov, “Podgotovka,” 69-74. See also Frolov, Predvoditeli; and N. V. Frolov, Vladimirskii rodoslovets, vol. 1 (Kovrov, 1996). 
208. Gorlanov, “Podgotovka,” 67-68; Frolov, Predvoditeli; idem, Vladimirskii, 77.

209. Gorlanov, “Podgotovka,” 72-73; “Spisok,” 25.

210. VGV, 1860, no. 4.

211. Mokhnacheva, Zhurnalistika, 40.

212. V. Iu. Afiani, "Periodicheskaia pechat' Rossii XVIII-XIX vekov kak istochnik po istorii russkoi provintsial'noi kul'tury: nekotorye itogi i perspektivy issledovaniia v kontekste programmy 'Kul'tura rossiiskoi provintsii, ”' in Otechestvennaia kul'tura i razvitie kraevedeniia, ed. S. O. Shmidt (Penza, 2001), 29.

213. Burmistrova, Provintsial'naia, 124, 127.

214. On Unkovskii, see Emmons, Russian, 79-151 and passim, and Daniel Field, The End of Serfdom: Nobility and Bureaucracy in Russia, 1855-1861 (Cambridge, Mass., 1976), 210-20.

215. I. P. Popov, “Mestnaia ofitsial'naia periodika v gody pervoi revoliutsionnoi situatsii (po materialam tsentral'nykh gubernii)," in Problemy istorii obshchestvennoi mysly i istoriografii: K 75-letiiu akademika M. V. Nechkinoi, ed. L. V. Cherepnin et al. (Moscow, 1976), 159.

216. Ibid.

217. Ibid., 161.

218. Ibid., 161-62.

219. Burmistrova, Provintsial'naia, 129.

220. L. V. Chekurin, Istoricheskoe kraevedenie: Istoriografiia i istochnikovedenie (Moscow, 1991), 75.

221. Popov, “Mestnaia,” 156.

222. Chekurin, Istoricheskoe, 77.

223. Ibid., 77-78. For the Riazan liberal minority, see Emmons, Russian, 176-80.

224. Chekurin, Istoricheskoe, 76, 83.

225. N. P. Matkhanova, “Avtory i chitateli Sibirskikh gubernskikh vedomostei v pervye gody ikh izdanii,” in Knizhnoe delo v Sibiri (konets XVIII-nachalo XX v.), ed. V. N. Volkova et al. (Novosibirsk, 1991), 51.

226. N. P. Matkhanova, “Sotrudnichestvo politicheskikh ssyl’nykh i obshchestvennykh deiatelei vostochnoi Sibiri v Irkutskikh gubernskikh vedomostiakh v 1857-1860 godakh,” in Ssylka i obshchestvenno-politicheskaia zhizn’v Sibiri (XVII-nachala XX vv.), ed. L. M. Goriushkin et 
al. (Novosibirsk, 1978), 208. See also Mark Bassin, Imperial Visions: Nationalist Imagination and Geographical Expansion in the Russian Far East, 1840-1865 (Cambridge, Eng., 1999). $109-11$.

227. Andrzej Walicki, A History of Russian Thought from the Enlightenment to Marxism (Stanford, 1979), 159.

228. Ibid., 161.

229. V. Aref’ev, “M. V. Butashevich-Petrashevskii v Sibiri,” Russkaia starina, no. 1-2 (1902): 177-78. Zagoskin's "first article," "Notes on the life of the residents of Irkutsk District," is termed "one of the first serious articles using local material" in Matkhanova, "Avtory," 52. In it, Zagoskin described the difficult life of the Siberian peasant, the rural administrators who "fed themselves from the work of the agriculturalist," and argued the peasant needed both "security of property and of the individual [lichnosti].” Quoted in Matkhanova, "Sotrudnichestvo,” 212.

230. Z. Ia. Ivanova, Istoki sibirskoi zhurnalistika: informatsiia, filosofiia, sotsiologiia (Chita, 1997), 121-22.

231. Matkhanova, "Sotrudnichestvo,” 213-17.

232. B. A. Chmykhalo, “K istorii stanovleniia pechati v Eniseiskoi gubernii,” Iz istorii literatury Sibiri (1976), 1: 51.

233. Petrashevskii wrote in protest of the duel, sending his petition on the matter to The Bell for publication. Matkhanova, "Sotrudnichestvo," 210, and The Bell 92 (February 15, 1861), in Kolokol: Gazeta A. I. Gertsena i N. P. Ogareva (Moscow, 1962), 4: 770-75.

234. Matkhanova, “Sotrudnichestvo,” 222-23.

235. See M. V. Butashevich-Petrashevskii, "Mestnoe obozrenie," in Istoriia sibirskoi pechati XVIII-nach. XX vv., comp. L. S. Liubimov (Irkutsk, 2004), 1: 54-60. 
Center for Russian \& East European Studies

University Center for International Studies

University of Pittsburgh

4400 W. W. Posvar Hall

Pittsburgh, Pennsylvania 15260

(412) 648-8716

www.ucis.pitt.edu/crees/cbpaper.html.

Ronald Linden, Bob Donnorummo, William Chase, Co-Editors

Eileen O’Malley, Managing Editor

Vera Dorosh Sebulsky, Editorial Assistant 